\title{
Exploring The Perceived Landscape with The Local People: The Experience of Community Mapping in Orduzu District (Malatya/Turkey)
}

\author{
Bilge Hatun Ay ${ }^{1 \odot}$, Aysun Tuna $2 \odot$ \\ ${ }^{1}$ Faculty of Fine Arts and Design, Inonu University, Malatya, Turkey. Email: bilgehatunay01@gmail.com
}

${ }^{2}$ Associate Professor, Faculty of Architecture, Bolu Abant Izzet Baysal University, Bolu, Turkey. (Corresponding author), Email: aysun.tuna@ibu.edu.tr

\begin{abstract} Purpose

The main purpose of the paper is to define historical landscapes through locals' perspectives and employs community mapping as a tool for defining and transferring perceived landscape elements Design/Methodology/Approach

The method used in this research consists of various stages, such as determining the boundaries of the study area, determining the goals and objectives of the community mapping, evaluation of the mapping process in the examined toolkits, and the community mapping process design specific to the study area according to the toolkits reviewed in the literature, and the outputs and observations obtained from the maps.

Findings

As a result of the community mapping study conducted with men and women separately, items under the themes of agriculture (past and present), hydrology, tangible cultural heritage, intangible cultural heritage, built environment, connectivity, flora and fauna were identified.

In this study, beyond the recognized physiographic features of the district, were discovered its "unseen" components due to the statements of locals and the analysis of the perceptual data they provided. Were acquired verbal information and point data about some archaeological sites that are not mentioned in any records or literature, as they remain undiscovered.

Research Limitations/Implications

This study bridged an establishing a new link with sustainable spatial planning by assessing perceptions of local people to the environment they live in. However, this study has limitations in the verbal and linear expressions of the groups participating in the mapping process.In the pre-mapping process needs to be supported by local government and non-governmental organizations for more participants.

\section{Social/Practical Implications}

it is suggested that the use of this methods such as spatial data production (on historical differences in landscape) within the mainframe of the participant planning approach and community mapping (to ensure collective wellbeing by creating healthy, sustainable spaces) and the inclusion of these methods in spatial planning stages will prove significantly useful.

\section{Originality/Value}

This study provides a framework for integrating different perspectives to better recognise and planning and manage the landscape character. This framework can be used as a foundation for a planning process in touch with "real life" and "users".
\end{abstract}

Keywords: Perceived landscape, community mapping, participatory mapping, sketch maps, landscape characterization, Orduzu, Malatya 


\section{INTRODUCTION}

With its multiple elements, the term "landscape" has various definitions. Landscape refers not only to a complex phenomenon that can be described and analysed using objective scientific methods but also to a subjective observation and experience and thus has a perceptive, aesthetical, artistic and existential meaning as well (Macpherson, 2005; Cosgrove \& Daniels, 1988; Lowenthal, 1975; Lowenthal, 1985). Antrop (2005) claimed that landscape has holistic, perceiving and dynamic characteristics. According to Johnson (2007) and Thomas (2012), landscape has meaning as the land itself (the land surface and its physical properties and features), as a matter of perception (cognition, meaning, and apprehension), and as a matter of relationships and experience (bodily engagement, practice, task, and movement) in other disciplines, especially archaeology (ScARF, 2012). According to Howard (2011), there are two predominant threads on landscape: the idea of the cultural landscape and landscape as a picture. Within the cross-section of all the definitions of the term "landscape", Johnson and Hunn (2010) highlighted the integrity of landscape by stating the following: "We emphasize landscape as perceived and imagined by the people who live in it, the land seen, used and occupied by the members of a local community, which encapsulates both land cover and land use" (Human Landscape Perception, 2013). The term "landscape" was given a common definition by the European Landscape Convention (ELC) undersigned by European countries. The ELC defines landscape as "an area, as perceived by people, whose character is the result of the action and interaction of natural and/or human factors" (Council of Europe, 2000). In this definition of landscape, the factor of perception stands out. Hunziker et al. (2007) reported that there are two major modes of perceiving landscapes: the physical properties of a landscape linked to biological inheritance, where the landscape is considered in space, and the sociocultural understanding, in which the landscape is understood as a place. Moreover, it is important not only to understand the landscape itself but also to understand the factors that affect the perceived landscape. Research by Jacobs (2006) divided the landscape into three separate realities: matterscape, powerscape and mindscape. Matterscape is the physical reality, powerscape is the social reality, and mindscape is the inner reality. Examining the landscape classification by Jacobs, it can be conferred that landscape perception is affected by physical landscape and individual and cultural influences, given that realities shape perception. In the research title "Demographic Correlates of Landscape Preference" by Lyons (1983), landscape perception was shown to differ significantly by age, gender and residential experience factors. She found that preference levels changed in different age groups, adolescent males and females had different preferences, urban and rural residents had different preferences, familiar vegetational biomes were most preferred, and there was no evidence that landscape preferences were shaped by innate or evolutionary factors. Within the scope of differing landscape 
perceptions in terms of gender aspects, the research by Perera and Chandrasekara (2017) was aimed at detecting perceptual changes in landscape architecture students and the local public in a study aimed at measuring the effect of a public landscape on different genders with different knowledge levels. According to the results, there is no clear difference in preference for landscapes between female and male public users. There is a significant difference in the order of perception according to gender among landscape undergraduate students. The other results of the paper indicate that landscape students have a comparatively better understanding of landscape than does the general public. The studies oriented at detecting the effects of different cultures (identities) on landscape perception show that cultures have a high correlation of preference (Herzog, et al., 2000; Kaplan \& Herbert, 1987; Kaplan \& Kaplan, 1989; Yang \& Kaplan, 1990; Priego, et al., 2008; Schenberg, 2008; Matijošaitienè, et al., 2014). Yu (1995) also reported that people from different living environments (rural vs. urban) have different preferences; rural residents have a high preference for novelty and modernity. He also indicated that landscape preferences are strongly influenced by education levels.

Due to archaeological findings and previous approaches, we are aware that the relation between religion and landscape perception dates back to the distant past. According to Doyle (2014), influenced by archaeological approaches to the ideologies of prehistoric Britain, AngloSaxons are increasingly devoting themselves to exploring the wider religious use and interpretation of the landscape. The Göbeklitepe Archaeological Site, included in the UNESCO World Heritage List in 2019, can be provided as the most significant example of human beings shaping the environment due to their religious beliefs in prehistoric times. Schmidt (2007) reports that the Göbeklitepe region is different from the Neolithic settlements found in other archaeological excavations and that religious structures that have not been encountered before have been identified. One such megalithic structure, at least 5,000 years older than known ancient temples, clearly indicates how significant and influential religious beliefs can be in the development of civilizations. Göbeklitepe also indicates that humans constructed impressive and complex buildings before their basic needs, such as housing, agriculture and pottery, were met, showing that these were induced by the strong sense of belief amidst archaic human communities. In fact, Scmidt (2007) defines Göbeklitepe as follows: "...first, the temple was built, and then, the city." Today, we can see that religion and religious rituals (such as the use of landscape descriptions in connection with the belief that the mountains of Hinduism are the house of God, the belief that forests and rivers are sacred and make up the Garden of Eden in Islam, and the connection between life and life after death) have a significant effect on shaping landscape perception.

In brief, it can be said that landscape perception is shaped by religion and individual influence on perception; education, individual hobbies, area of 
interest, age, gender, and cultural influence on perception; and nationality, class, social value/rules, economic, political conditions, and residential background of urbanization.

\section{Landscape Typification and Characterization}

The answer to one question-"How are perceived landscapes defined and integrated into the modern urbanization process?"—can be sought in the definition of landscape by the European Landscape Convention (ELC). It is reported that the definition of landscape also includes character, and the determination and classification of character types play a key role in the implementation of the ELC (Butler \& Berglund, 2014). Tudor (2014) defines landscape character evaluation as the process of defining and explaining differences and changes in landscape character. In this process, the objective is to identify and explain the unique composition of the elements and features (characteristics) that render landscapes different. In such landscape character analysis, which is a method for identifying the perceived landscape, natural (topography, soil, vegetation, geology, etc.) and cultural (land use, settlement type, historical places, etc.) data are transferred to the GIS environment, together with the data obtained from the land survey. For each landscape character area and type, the key pressures of its important properties, qualities, spatial distributions and changes that can affect its character and biological diversity are determined. At the end of the process, the final decision or decisions are made based on landscape development strategies, landscape planning policy guide, landscape capacity and landscape development suggestions.

\section{Historic Landscape Characterization}

Historic Landscape Characterization (HLC) differs significantly from more traditional methods of describing historical sources, such as a list of areas of protected cultural heritage. As specified in the ELC, historical landscape assessment studies are closely related to the definition of the term "landscape", involving areas shaped by natural and/or human activities and interactions. The outputs of this assessment, which focus on human-based factors, provide complementary contributions through presenting a relatively more historical dimension in the landscape character analysis and assessment process (Demir \& Demirel 2016; Fairclough, 2014; Shropshire County Council, 2007; Turner; 2006). The HLC approach, which is based on an archaeological view of the landscape as a material culture and artefact, treats the landscape as a perception of the environment. This method is oriented towards the elements of time (time-depth), the role of human beings, and the dynamics of changes (Stular, 2011). Within the scope of this classification, landscape patterns, such as land size and form (closed, zoned, semi-closed, regular-irregular areas, etc.), current land use (forest, agricultural field, settlement area, etc.), the previous usages of landscapes, and the tangible cultural remains from the patterns (remains from the medieval age, classical age, post- 
classical age, etc.) or any single dominant pattern, structure and trace are clearly described. Character areas are defined using timewise changes by means of using historical photos, drawings, gravures, and old-dated air photos in GIS media. HLCs are beginning to be used in strategic planning policy, where they can contribute to national or regional objectives and the planning of major developments such as wind farms and can advise on land management issues, such as agri-environment schemes, woodland grant schemes and heathland regeneration schemes (Macinnes, 2003).

\section{Participatory Mapping (Community Mapping)}

Within the scope of defining perceived landscapes and the related decision-making process, the landscape types that are designated only by experts in technical departments and the practices exercised with the developed decisions are known to be the only areas where problems are experienced. One of the leading reasons may be the inability to ensure the participation of local citizens in the planning, management and decisionmaking processes of cultural landscapes, which are formed by experiences, gaining an identity through traditional use and constituting the collective memory with life practices.

Land use and development decisions are consistently among the most important decisions at the community level because they are perceived to have direct linkages to resident quality of life (Brown, 2006). To activate each and every dynamic within the structure of the landscape, the community mapping method aims to present the details of the current situations through community gatherings and to improve social accountability and environmental awareness through revealing feelings and opinions. The community mapping method presents the natural and cultural landscape resource assets of the local community and the tangible and intangible cultural heritage resources, as well as other potential solutions for the problems experienced through gathering individuals of different gender, age, ethnic group and socio-economic status living in the same area (Lydon, 2002; Armstrong, 2008; UNHCR, 2008). Community maps show how the local community sees their area through the use of maps and photos. Community mapping states the common basis that the community shares by means of establishing or exploring its connections (Lydon, 2003; Offen, 2003; Parker, 2006; Perkins, 2007). Used as a participative action research tool, the community mapping method has been recognized as the best practice in terms of sustainable development, with its contribution in revealing the secret potential of the landscape within the scope of its effects on local development in the United Nations Rio Environment Conference in 1992 (Panek \& Sobotova, 2015; Cabeça et al., 2019).

Community mapping has been experienced for various purposes in various regions across the world and for various purposes. These experiences can be exemplified in terms of rural and urban planning scenarios. Within the scope of rural planning, community mapping 
studies have been substantially used in the establishment of ecomuseums projected for Italy. With the collaborative studies and works carried out with the local communities living in the region for the planning phases of the Ecomuseum of Parabiago Landscape, Ecomuseo Della Castagna Raggiolo, Ecomuseo Della Pietraporzio, and Ecomuseo Regionale delle Miniere e della Val Germanasca, planning and landscape studies have been carried out in line with such information as the potential of the local landscape, along with its problems, the changes experienced from past to date and biodiversity. The study of Wartman and Purves (2017) is an example of using the community mapping method to explore landscape categorization in rural areas. The mapping process that was carried out with Takana indigenous people in the Bolivian Amazon reflects local conceptualizations and land use, which can be considered, for instance, in resource management and spatial planning. The above study also shows considerable differences among the features represented on sketch maps with ethno-ecological landscape categories used in language. Examining the community mapping examples carried out in urban areas, the study by Panek and Sobotova (2015) in Nairobi (Kenya) stands out. They discussed the possible effects of community mapping on local development. Integrating the results with the participatory GIS, they aimed unlock the hidden potential in urbanslum areas in Nairobi, and further examined possible future development in the area of community mapping. The results of this experience show that the participation of the local community is crucial for the success of the mapping project. Panek and Sabotova (2015) drew attention to the link between technological demanding and participation levels in their research. As a result of the research, they determined that the more technology instruments in planning such as GIS, remote sensing or geodetic mapping dominate the mapping process, the less members of the community are actively involved, and thus the chances of sustainability decrease.

\section{Study Area}

With the use of a community mapping method, this paper aims to define the perceived landscape of Orduzu District, located within the district of Battalgazi, Malatya Province in the Eastern Anatolia Region of Turkey (Fig.1). The following criteria have been defined for choosing the Orduzu district: this district has hosted many civilizations in the historical development process, it possesses multiple cultural layers, the traditional landscape texture (settlement structure, production method, neighbouring relations, etc.) has been relatively preserved when we look at it in the present, and neighbourhood residents comprise a substantial proportion of the local public. 
Figure 1. Location of Orduzu District in Malatya City

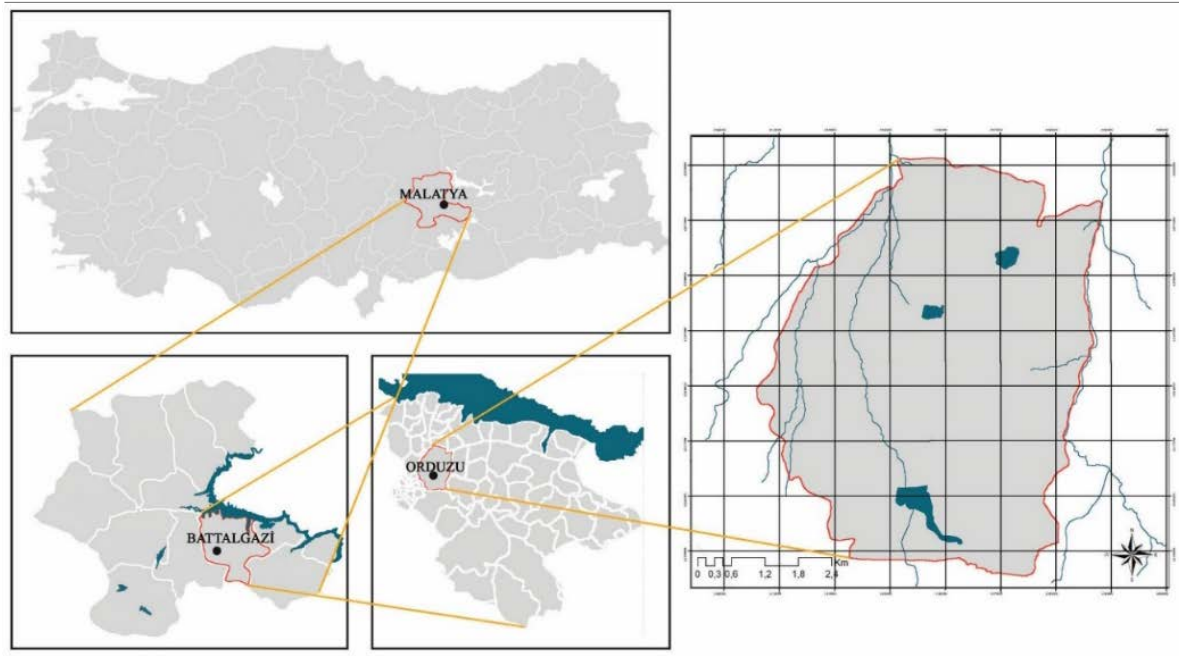

It is known that the settlement date of the Orduzu District dates back to the prehistoric period. This information comes from the Arslantepe Mound, which began to form in 1930 (the first systematic excavations were funded by the University of Rome La Sapienza in 1962), based on the data obtained from archaeological excavations. The cultural embankment of the Arslantepe Mound is 30 metres high. It was inhabited from $5000 \mathrm{BC}$ until the 11th century BC. It was used as a Roman village between the fifth and sixth centuries AC and later was turned into a settlement-the Byzantine Necropolis (cemetery) (Frangipane, 2012). Following the excavations carried out since 1930, it has been accepted that this area has a multi-layered artificial form. It is known that it was named after the lion sculpture made of stone and found at the entrance of the palace at the beginning of the first millennium BC (Frangipane, 2012). It had a state structure and covered the Eastern Anatolian and Mesopotamian communities in $4000 \mathrm{BC}$, it supports developments such as monumental architecture and iconography with this multi-cultural structure, and in this sense, it is known to be the most well-preserved and oldest mud-brick palace with wall paintings. With its hosting characteristics, the Arslantepe Mound has been included in the UNESCO World Heritage Temporary List as of 2014 (UNESCO, 2014). With its characteristics along with its importance in explaining a crucial part of the history of humankind, its located structures, and its significant documenting stages over the world as a single unique area of human development, it was nominated as Turkey's candidate to permanently become a UNESCO World Heritage Site in 2019.

Many ceramic pieces from the Byzantine, Seljuk and Ottoman Periods have been found during the surveys carried out in the Orduzu District (Di Nocera, 2008). According to the findings, we can see that this area was used as a settlement area in later periods. Today, it is conferred that in Orduzu, which is established on a wide valley floor, its rich hydrological features, agricultural areas and orchards are densely spread (Figure 2). 

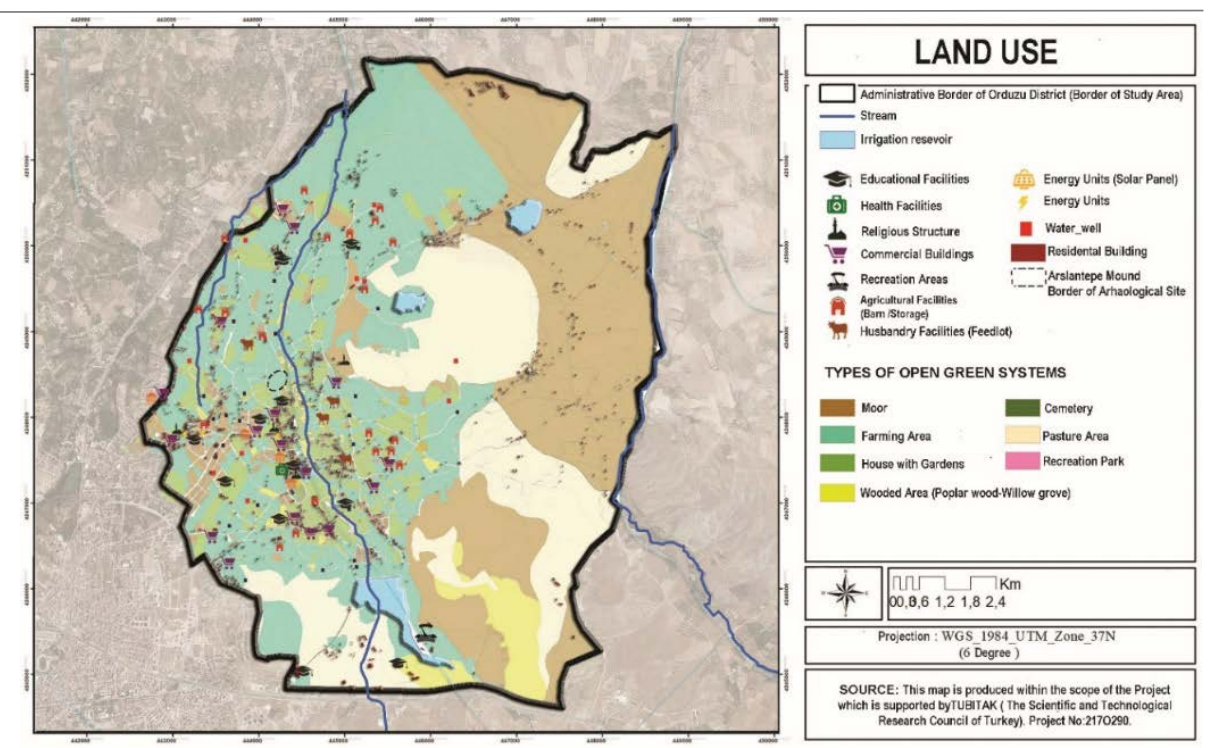

\section{Methodology}

The main purpose of the paper is to define the cultural landscapes of the study area by the local people using the community mapping method. With this method, it is aimed to understand the landscape potential of the study area with local people, identifying the problems and developing realistic and sustainable solutions to these problems.

In order to learn community mapping processes and techniques, studies in this field have been examined. In this research, is focused on toolkits that explain the mapping process and the implementation stages with the case studies. In the paper, it was used the booklets published by Penrith City Council and University of Western Sydney and Vale of Glamorgan as the materials, among the toolkits examined. The community mapping process in these toolkits is shown in Table 1 and Table 2 .

The method used in this research consists of various stages, such as determining the boundaries of the study area, determining the goals and objectives of the community mapping, evaluation of the mapping process in the examined toolkits, and the community mapping process design specific to the study area according to the toolkits, and the outputs and observations obtained from the maps. The flow chart of the research method is shown in Figure 3.
Figure 2. The Map of Land Use of Orduzu District in Malatya City 
Exploring the Perceived Landscape with The Local People: The Experience of Community Mapping in Orduzu District (Malatya/Turkey)

Table 1. The Creative Community Mapping Toolkits published by Penrith City Council and University of Western Sydney (Armstrong et al., 2008)

\begin{tabular}{|c|c|c|c|c|}
\hline Aim & $\begin{array}{l}\text { Target } \\
\text { groups }\end{array}$ & Mapping Process & $\begin{array}{c}\text { The } \\
\text { Materials } \\
\text { Used }\end{array}$ & Outputs \\
\hline $\begin{array}{l}\text { To develop } \\
\text { an } \\
\text { understandi } \\
\text { ng of the } \\
\text { cultural } \\
\text { values } \\
\text { related to } \\
\text { existing } \\
\text { parks and } \\
\text { outdoor } \\
\text { recreational } \\
\text { space in } \\
\text { Penrith }\end{array}$ & $\begin{array}{l}\text { Childre } \\
\text { n from } \\
\text { Kindan } \\
\text { a After } \\
\text { School } \\
\text { Care } \\
\text { Centre }\end{array}$ & $\begin{array}{l}\text { Pre-mapping Initial } \\
\text { Discussion, } \\
\text { introduce the Project } \\
\text { information } \\
\text { requested from } \\
\text { children } \\
\text { write down stories } \\
\text { about parks they } \\
\text { enjoyed and their } \\
\text { parent's stories } \\
\text { games played in } \\
\text { parks collect small } \\
\text { to cos leaves } \\
\text { things such as le } \\
\text { etc. from the parks. } \\
\text { Workshop One: } \\
\text { Engaging with a } \\
\text { Park } \\
\text { "What people } \\
\text { do/find in parks" } \\
\text { "Why we do this in } \\
\text { parks" } \\
\text { "What we don't do in } \\
\text { parks } \\
\text { Making the Map } \\
\text { (Collective) } \\
\text { Building up } \\
\text { Descriptive Words } \\
\text { Workshop Two: } \\
\text { Making Individual } \\
\text { Maps } \\
\text { Mapping Favourite } \\
\text { Parks. } \\
\text { Mapping Not-Nice } \\
\text { Parks } \\
\text { Discussion of } \\
\text { Children's } \\
\text { Workshops }\end{array}$ & $\begin{array}{l}\text { coloured } \\
\text { folders with } \\
\text { pens, } \\
\text { drawing } \\
\text { paper, } \\
\text { notebooks } \\
\text { and a } \\
\text { personal } \\
\text { letter. } \\
\text { 3mx3m black } \\
\text { mapping } \\
\text { base, } \\
\text { individual- } \\
\text { coloured } \\
\text { boards, each } \\
600 \mathrm{~mm} 800 \\
\text { mm }\end{array}$ & $\begin{array}{l}\text { Children revealed } \\
\text { that their use of } \\
\text { parks and open } \\
\text { space is changing } \\
\text { from general play } \\
\text { in neighbourhood } \\
\text { open space to } \\
\text { organised } \\
\text { activities on } \\
\text { playing fields at } \\
\text { prescribed times. } \\
\text { Their out of } \\
\text { school activities } \\
\text { seem to be } \\
\text { increasingly } \\
\text { structured, as a } \\
\text { result many of } \\
\text { them are not } \\
\text { using local parks. }\end{array}$ \\
\hline $\begin{array}{l}\text { To develop } \\
\text { creative } \\
\text { community } \\
\text { mapping as } \\
\text { an original } \\
\text { design and } \\
\text { planning tool } \\
\text { for Penrith. }\end{array}$ & $\begin{array}{l}\text { Student } \\
\mathrm{s} \text { of } \\
\text { Univers } \\
\text { ity of } \\
\text { Wester } \\
\mathrm{n} \\
\text { Sydney }\end{array}$ & $\begin{array}{l}\text { Pre-Mapping } \\
\text { individuals visited } \\
\text { the places, wrote } \\
\text { down emotions, both } \\
\text { positive and } \\
\text { negative } \\
\text { Workshop Design } \\
\text { Map One: Map of the } \\
\text { Known } \\
\text { Map Two: Map of } \\
\text { Personal Landmarks } \\
\text { Map Three: Mapping } \\
\text { Layers of } \\
\text { Memory and } \\
\text { Experience } \\
\text { Map Four: Map of } \\
\text { Discomforting Places } \\
\text { Observations }\end{array}$ & $\begin{array}{l}\text { Using Google } \\
\text { Maps } \\
\text { For each } \\
\text { participant, } \\
\text { four A3 } \\
\text { copies of the } \\
\text { defined areas } \\
\text { were printed } \\
\text { out, digital } \\
\text { images, } \\
\text { coloured } \\
\text { cotton, pins, } \\
\text { tags }\end{array}$ & $\begin{array}{l}\text { Youth groups } \\
\text { indicated that a } \\
\text { diversity of } \\
\text { places is used for } \\
\text { open space } \\
\text { recreation. They } \\
\text { are however } \\
\text { restricted from } \\
\text { using parks and } \\
\text { open space at } \\
\text { night because of } \\
\text { the lack of lights. } \\
\text { They are also } \\
\text { prevented from } \\
\text { gathering in the } \\
\text { open space } \\
\text { around Westfield } \\
\text { by security } \\
\text { guards. }\end{array}$ \\
\hline
\end{tabular}




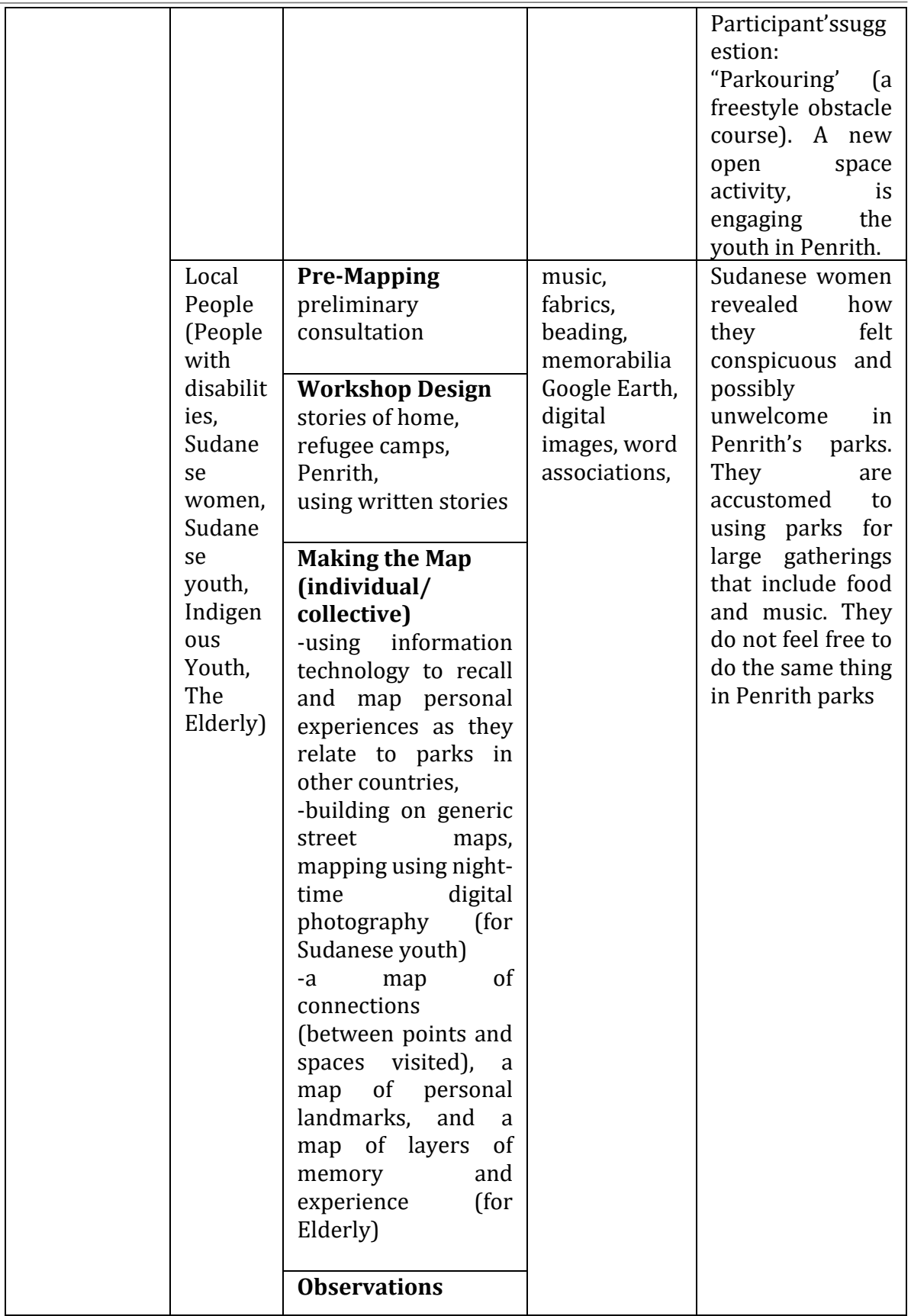

Table 2. The Community Mapping Toolkits published by Vale of Glamorgan (as part of the pilot project coordinated by the Creative Rural Communities Team) (Vale of Glamorgan Council, 2017)

\begin{tabular}{|c|c|c|c|c|}
\hline Aim & $\begin{array}{l}\text { Target } \\
\text { groups }\end{array}$ & $\begin{array}{l}\text { Mapping } \\
\text { Process }\end{array}$ & Mapping Activities & Outputs \\
\hline $\begin{array}{l}\text { Building } \\
\text { on and } \\
\text { expandin } \\
\mathrm{g} \text { existing } \\
\text { communi } \\
\text { ty } \\
\text { strengths }\end{array}$ & $\begin{array}{l}\text { Local } \\
\text { people } \\
\text { from } \\
\text { St.Atha } \\
\mathrm{n} \\
\text { in Vale } \\
\text { of }\end{array}$ & $\begin{array}{l}\text { Pre- } \\
\text { mapping } \\
\text { sets out the } \\
\text { work } \\
\text { involved } \\
\text { before the } \\
\text { mapping can } \\
\text { take place. }\end{array}$ & $\begin{array}{l}\text { Ice breakers } \\
\text { a way of ensuring that all } \\
\text { participants start to talk to } \\
\text { one another and find out the } \\
\text { names of people in their } \\
\text { community. } \\
\text { Community Photo Quiz } \\
\text { an activity to give each } \\
\text { group a page of photos of }\end{array}$ & $\begin{array}{l}\text { St. Athan: } \\
\text { The need to } \\
\text { improve } \\
\text { playgrounds } \\
\text { and more } \\
\text { activities for } \\
\text { children }\end{array}$ \\
\hline
\end{tabular}


Exploring the Perceived Landscape with The Local People: The Experience of Community Mapping in Orduzu District (Malatya/Turkey)

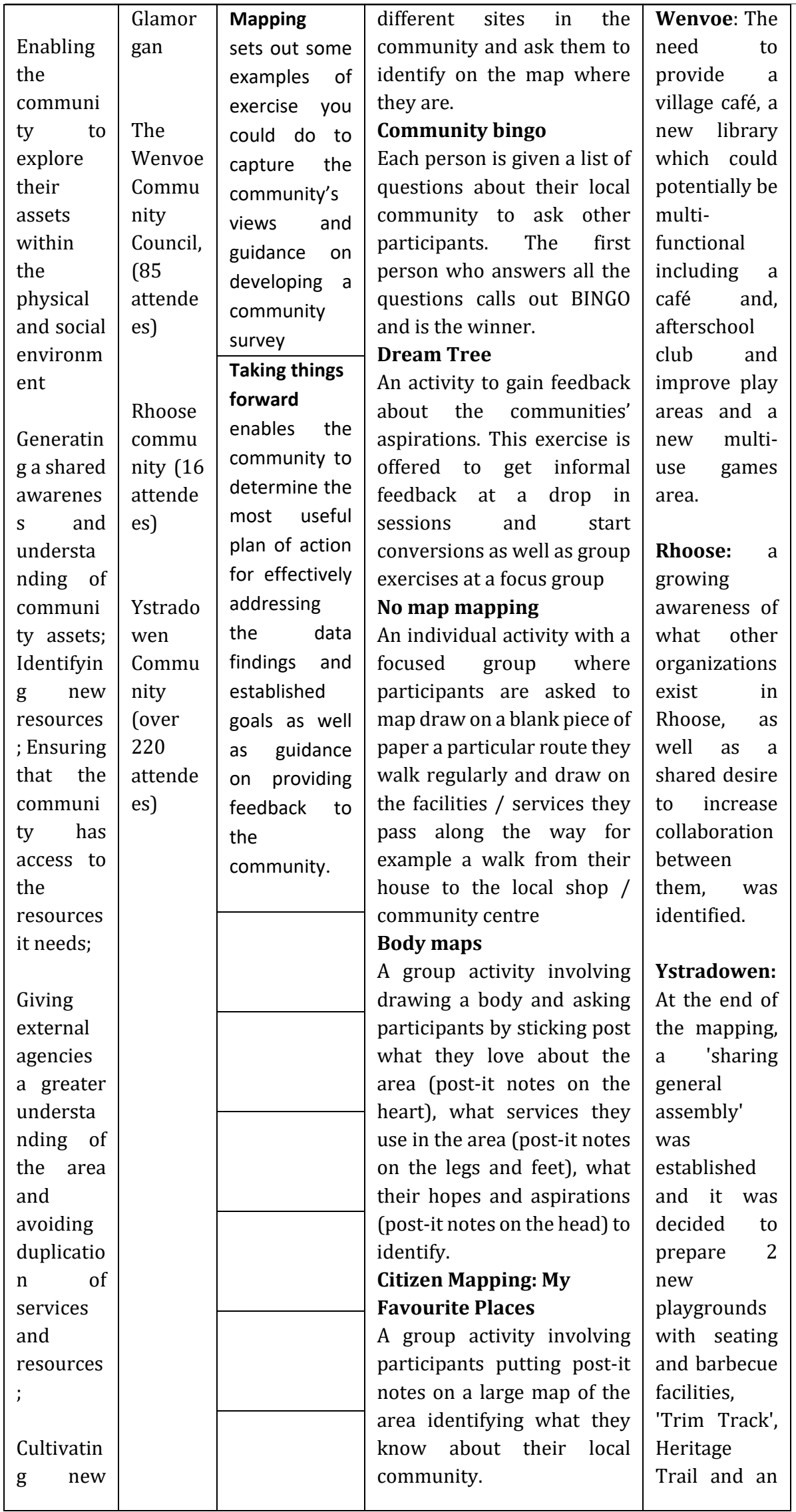




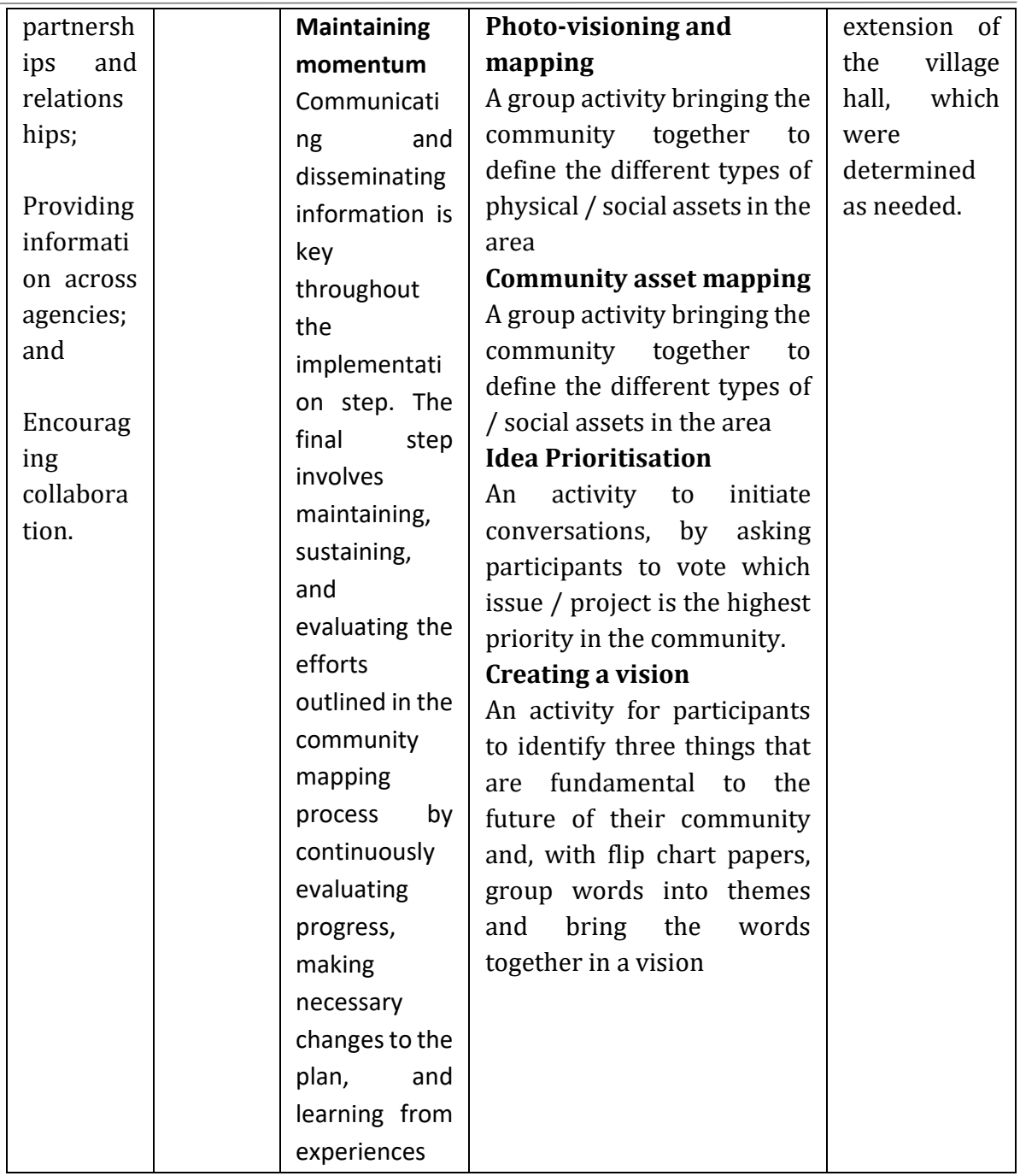

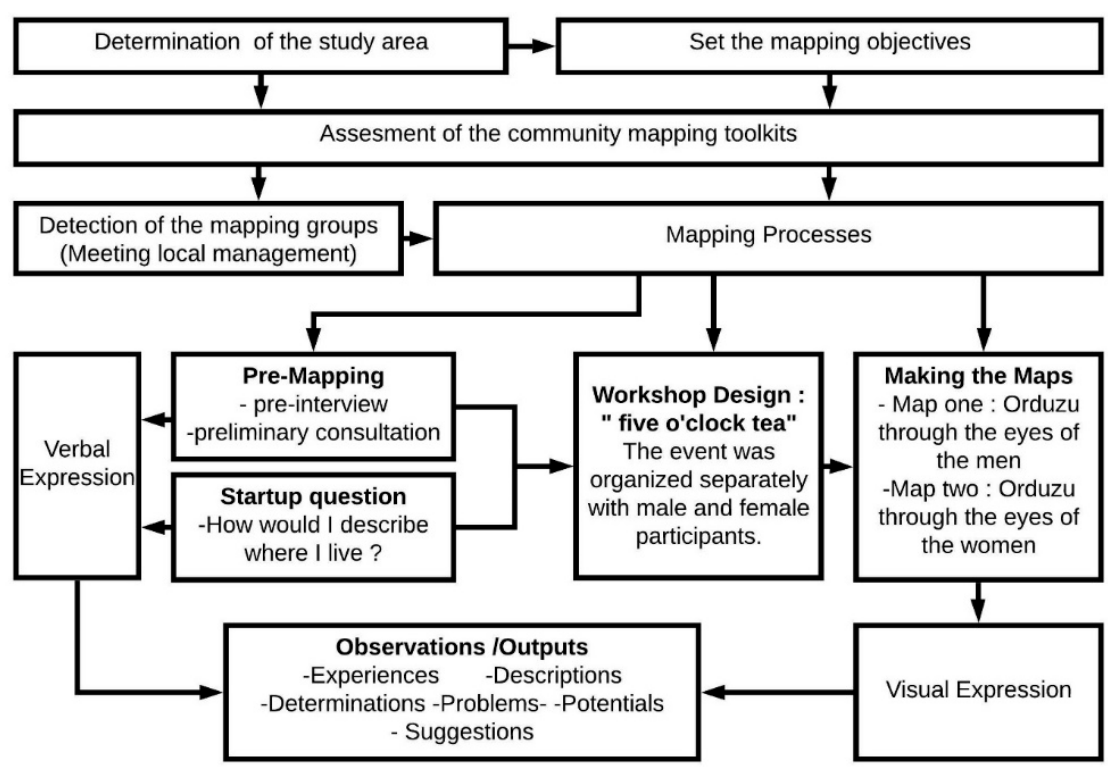

\section{Pre-Mapping: Conservation with Local Management}

The most critical point in this experience is the questions on ensuring participation in the mapping process and with whom the process is to be

Figure 3. The flow chart of the research method 
performed. Looking at the case studies conferred, the role of local governments is critical in the smooth execution of the process. Based on this, interviews were conducted with the upper- and lower-scale local government departments of Orduzu District. First, informative meetings were held for the purpose and importance of the community mapping method and especially its role in management. The first meeting was held on 23rd July 2019 within the Battalgazi Municipality, which is the district administrative management unit. On 30th July 2019, an informative meeting was held with the mukhtar (headman) of the district and the delegation under the coordination of the Battalgazi Municipality Culture Directorate. Following this meeting, discussions on the selection of participants were conducted during the mapping process. The mapping process aimed to achieve mixed participation, where all segments of society were together, without considering criteria such as gender, ethnicity, belief, age, and economic structure. However, in these meetings, there was a common discourse about the efficiency of the targeted expression in the mixed-participation stages by spokespersons and therefore the necessity of gender discrimination. Based on this, participation groups were formed by gender, and group studies were conducted at different times.

\section{Pre-Mapping: Community Mapping with Local People}

The following criteria were considered in the selection of individuals in the male and female groups: living in Orduzu for at least 10 years, having different professions, being in different ethnic groups, and being in different age groups. Regarding the perception of the living environment, it is of importance to bring together the subjective interpretation of the socio-cultural differences of individuals and therefore generate multiple meanings in the perception of the living environment and the shared space. In this framework, participant groups based on volunteerism were created. (Figs. 4-7). The groups were formed as follows: female participant group: 17 years ( 1 person), 25 years ( 1 person), 35 years ( 2 people), 45 years ( 6 people), and 46 years and above ( 5 people); male participant group: 17 years ( 1 person), 25 years ( 2 people), 35 years ( 4 people), 45 years ( 2 people), 46 years and above (13 people).

Figure 4: Meetings with Orduzu District Local Government Representatives (Photograph by author)

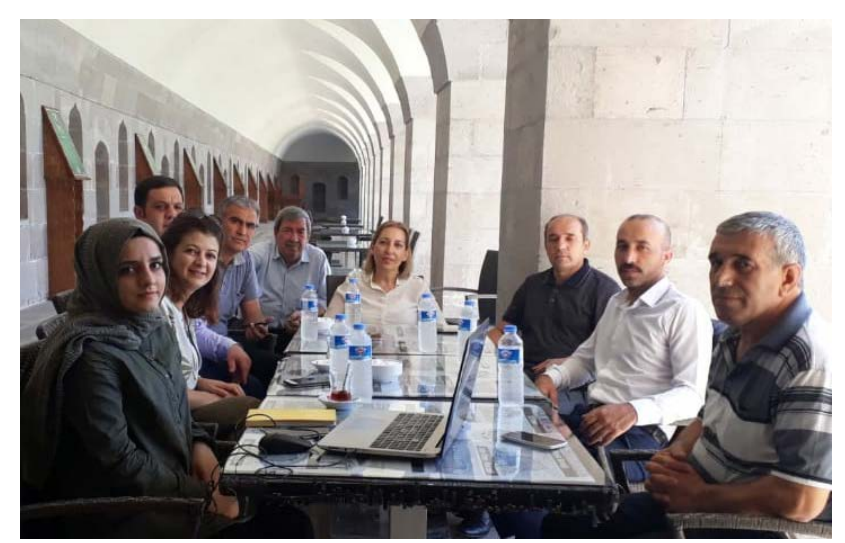



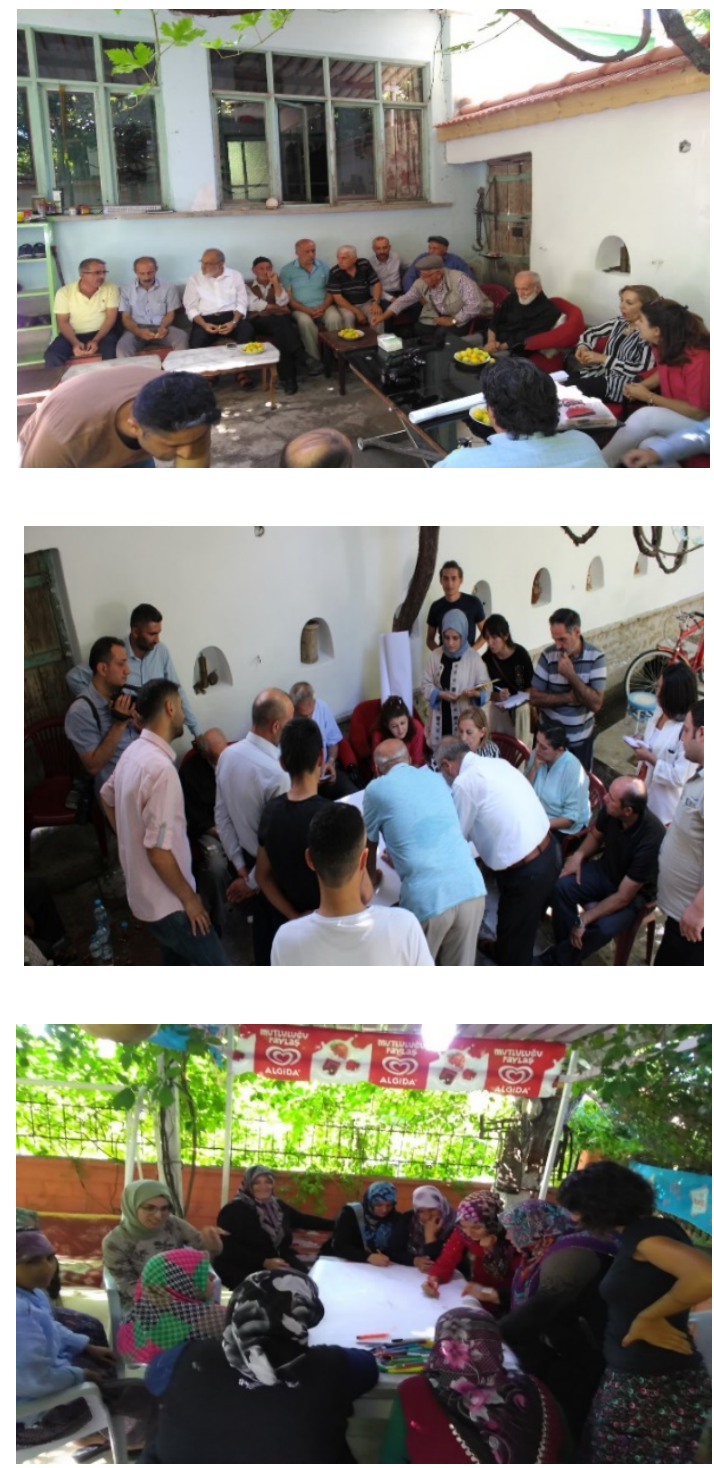

Figure 5: Meetings with Orduzu District Local People (Men) Participant Groups ((Photograph by author)

Figure 6: Meetings with Orduzu District Local People (Men) Participant Groups (Photograph by author)

Figure 7: Meetings with Orduzu District Local People (Women) Participant Groups (Photograph by author)

In the stages of the examined toolkits is seen that the activities have an important role for the efficient mapping process. During the mapping process, we determined that different workshop designs were carried out according to socio-cultural structure and age groups for the targeted groups. Based on this, we preferred the traditional activities of the neighbourhood as the workshop design for the community mapping process in the study area. It has been determined as the workshop event, called the "five o'clock tea", where the local people come together with each other. We were invited to two houses that hosted voluntarily for this event, which is usually held in the afternoon and where local dishes are served.

First, information was provided about the aim and purpose of the study. Afterwards, "How would I describe where I live?" was asked the starting question the participants. The process, which started with verbal dialogues without any direction, continued with visual expressions by giving A0 size white paper, coloured crayons, and coloured adhesive 
featured papers (note papers, etc.). The purpose of giving blank paper is to enable participants to express themselves freely. The stages of the drawing, the dialogues while drawing and the stories told were recorded (Fig. 8)

\section{RESULTS}

In the preparation process of community mapping, interviews and questionnaire techniques were used with participant groups. For verbal expressions, both groups first made a comparison with the present time by explaining the previous environment in which they lived. It was observed that these verbal expressions focused on the Arslantepe Mound. They evaluated the bond established with the Italian excavation team, along with the memories experienced, the contributions to the Orduzu neighbourhood and the people (making economic contributions to the local people during the excavation season, etc.). It was observed that the members of both groups actively participated in these verbal expressions. In the verbal expression stage, while the male group focused on describing the place in which they live, the female group mostly expressed their problems and expectations.

It was observed that the male group actively participated, and the majority of members of the female group remained hesitant when asked to proceed to the drawing stage after verbal expression. We voluntarily evaluated the community maps drawn by male and female participants both formally and contextually. In terms of stylistic features, the male group drew aerial views with a high vantage point, while the female group drew a mix of aerial and sideways perspectives. Both groups drew the neighbourhood in which they live in a circular form. While the male group divided the neighbourhood into four regions (old administrative boundaries that are not currently valid), the female group set the boundaries according to the present-day street names. Both groups drew the Arslantepe Mound as the centre of their maps.

Figure 8: Example of community map with aerial view and high level of abstraction of men group

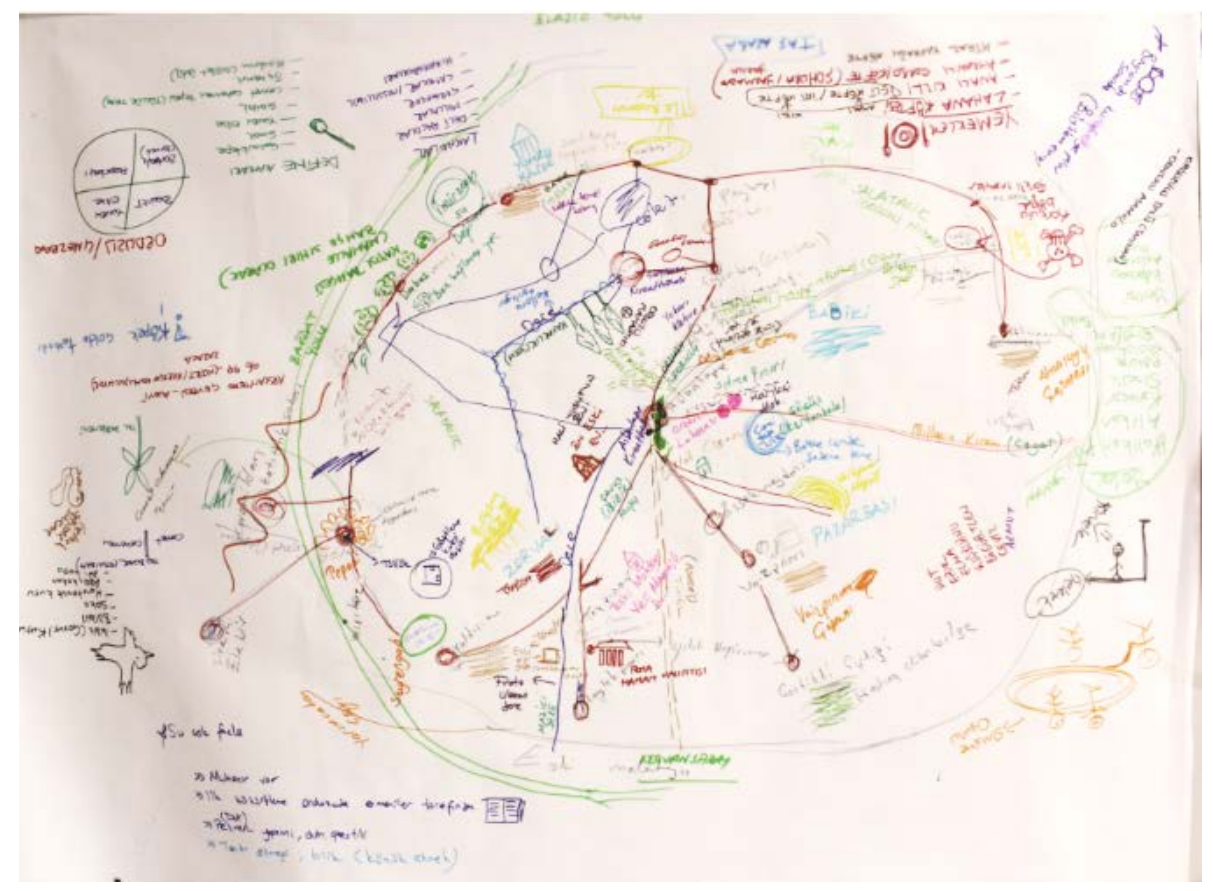




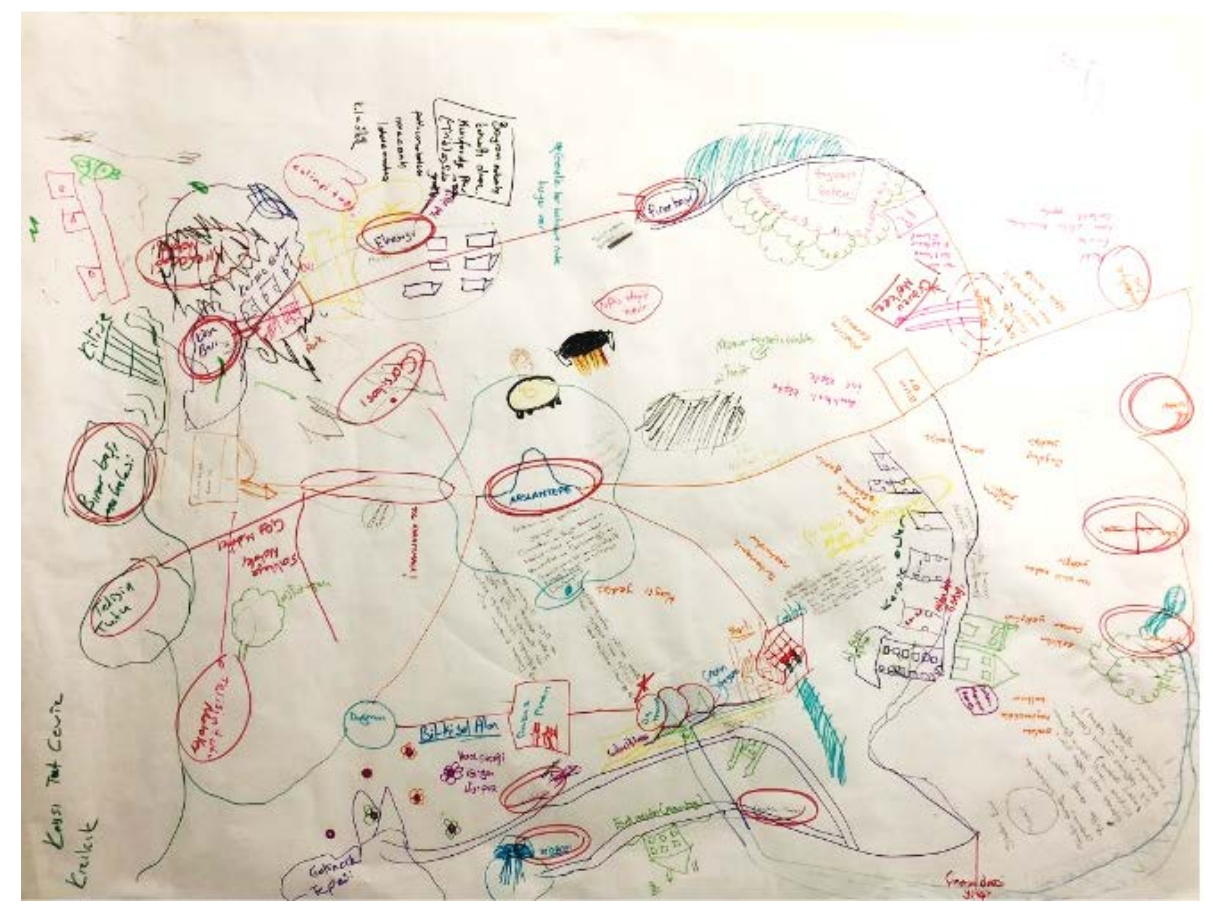

Analysing the formal language of the groups, it was determined that the locations drawn by the male group from the aerial viewpoint and their positions with each other reflect the existing land use, while there were errors in the geographical positioning of the women's drawings. It was observed that the female group drew the locations stated in the drawing according to the houses in which they lived (Fig. 8-9).

The items expressed in the community maps of both groups and the positioning stages (in the order of drawings) on the map are presented graphically in Table 3.

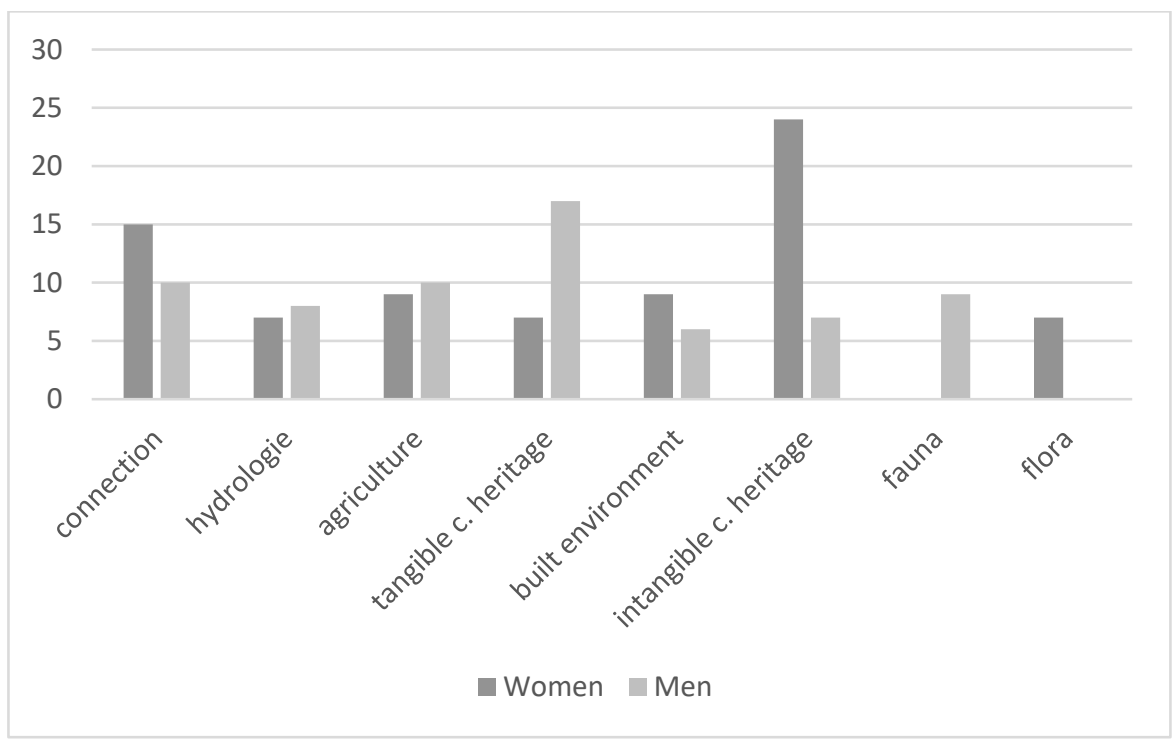

Figure 9: Example of community map with a blend of aerial and sideways perspective of women group
Figure 10: Comparison between historical landscape elements and features on community maps 
The community maps included in the table present the content. The topics of the groups are numbered in the order of drawing. In the mapping process, the local names are given in the table since they define the items drawn by the groups in the local language. Examining Table 4 both groups of community maps are generally composed of items under the themes of agriculture (past and today), hydrology, tangible cultural heritage, intangible cultural heritage, built environment, connection, flora and fauna. The distribution of the numbers of the items drawn under these titles according to the groups are presented in Figure 10.

Table 3. Formalistical Comparison of Community Maps of Man and Woman Groups: The Historical Landscape Elements on the Mapping (Drawing) Stages (Graphical Expression)

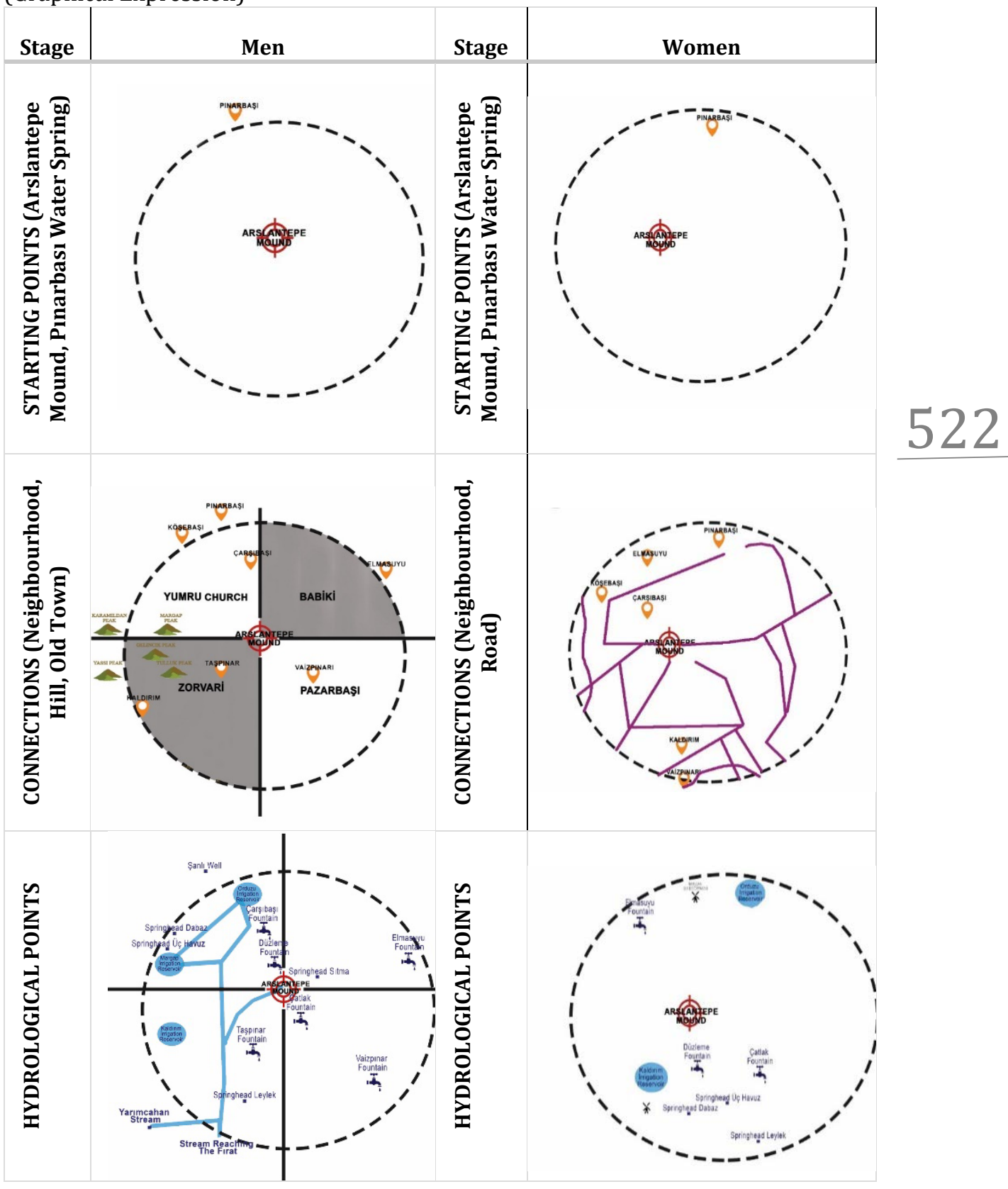



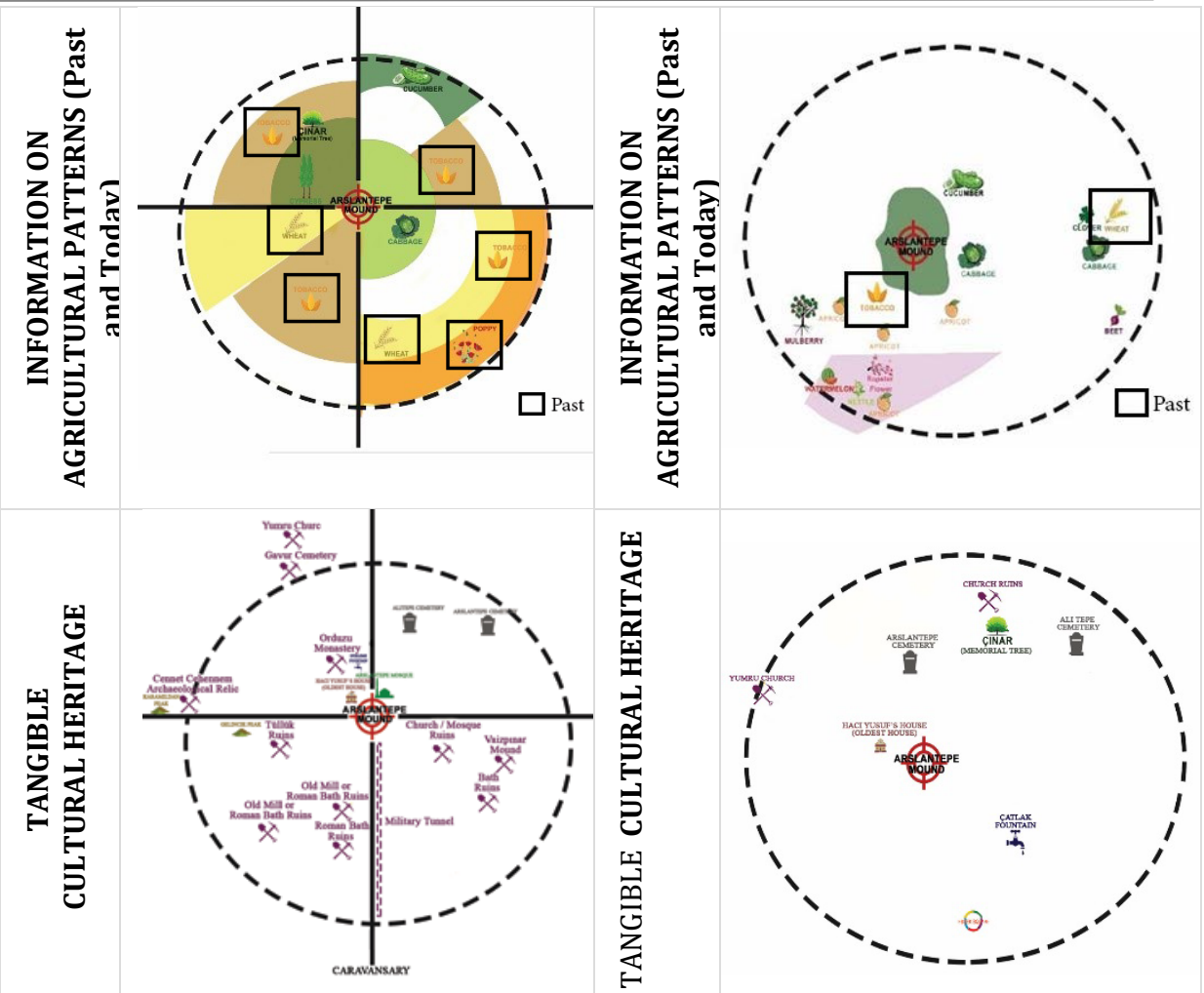

523

던
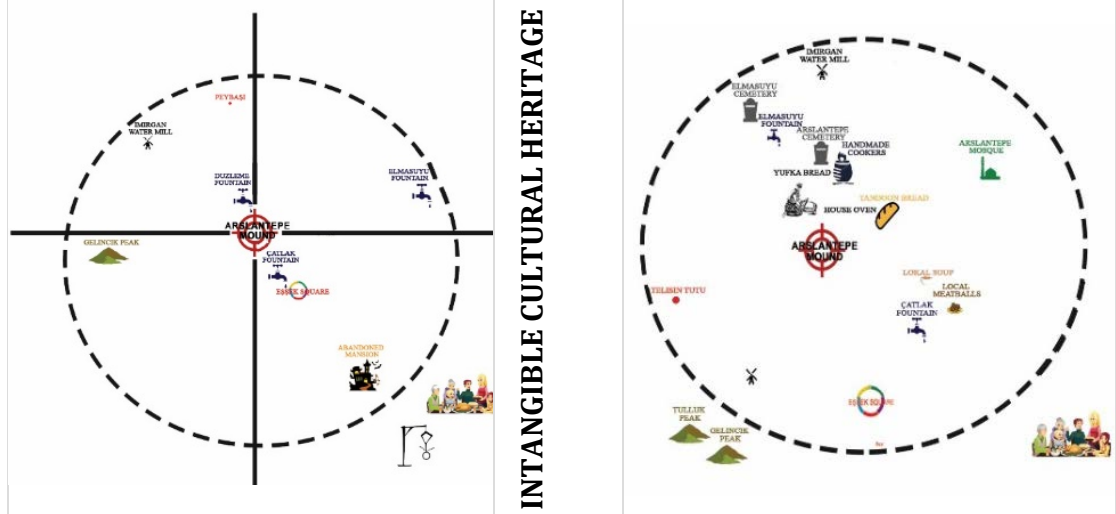

R
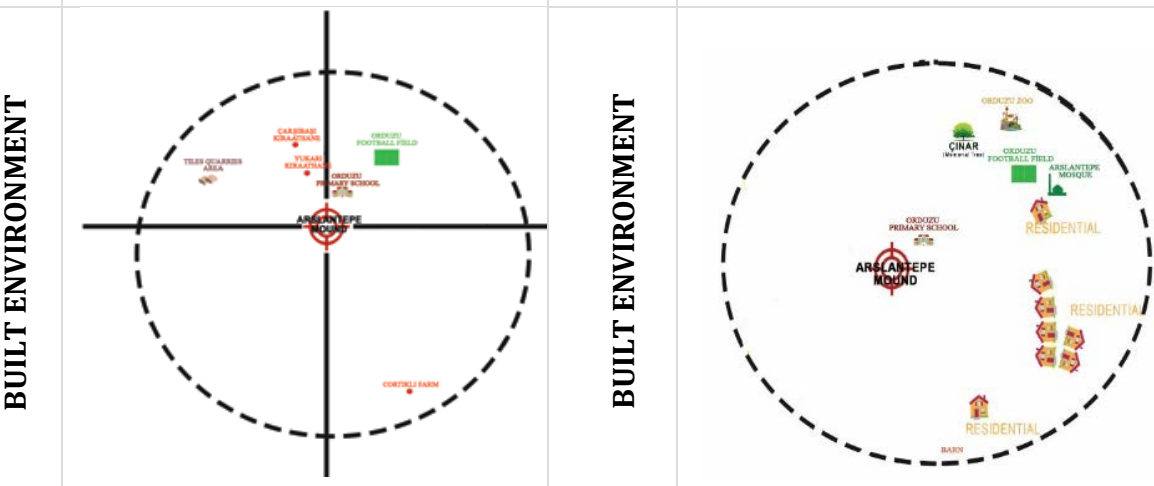


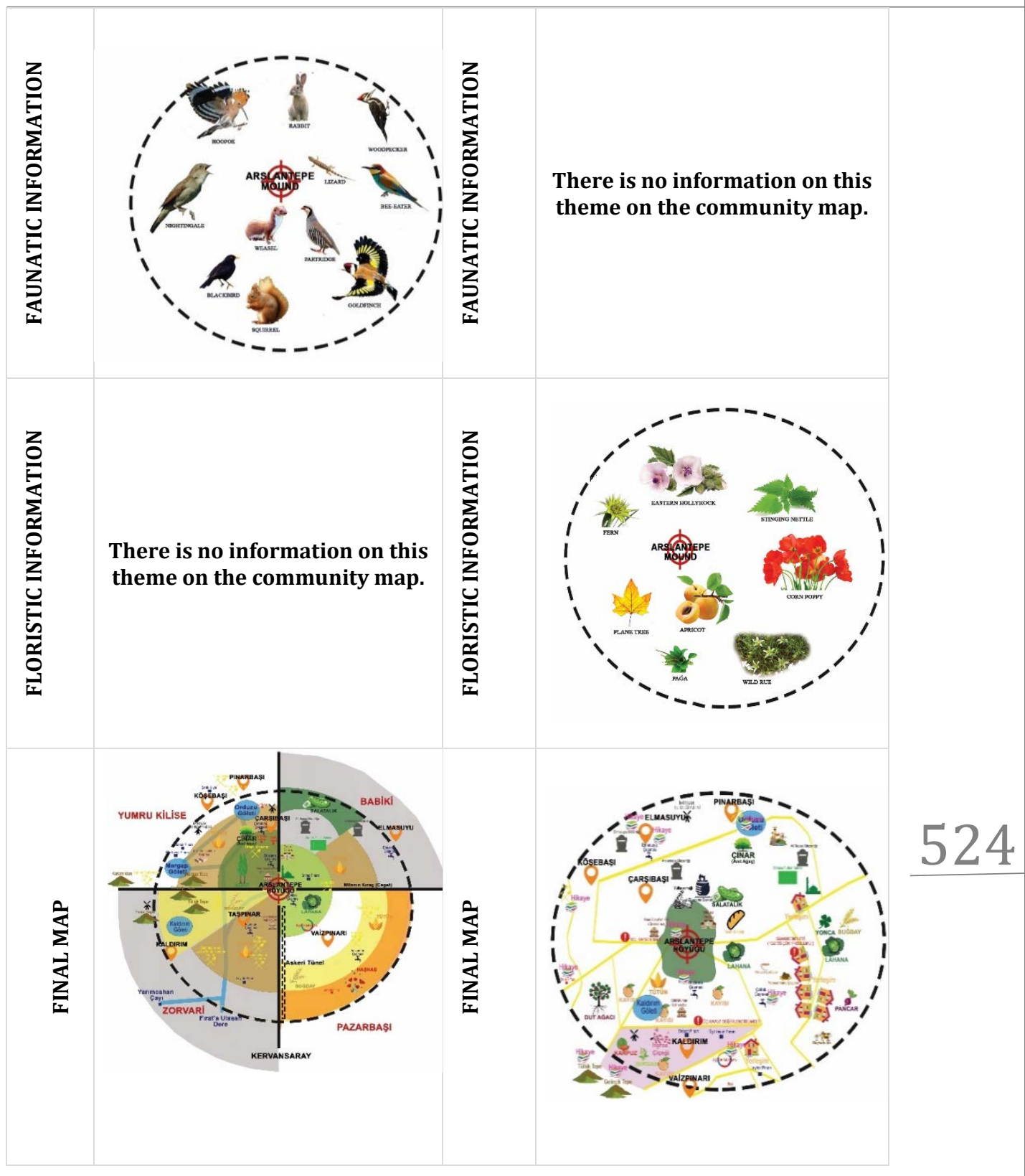

Table 4. Content-Wise Comparison of Community Maps of Man and Woman Groups

\begin{tabular}{|c|c|c|c|c|c|c|c|}
\hline \multicolumn{4}{|c|}{ Men } & \multicolumn{4}{|c|}{ Women } \\
\hline $\begin{array}{l}\text { Sketching } \\
\text { Stage }\end{array}$ & $\begin{array}{l}\text { Feature/ } \\
\text { some of } \\
\text { in Local } \\
\text { Turkish } \\
\text { Dialect }\end{array}$ & $\begin{array}{l}\text { Features } \\
\text { in Topics }\end{array}$ & $\begin{array}{l}\text { To } \\
\text { tal } \\
\text { Ite } \\
\mathrm{m}\end{array}$ & $\begin{array}{l}\text { Sketchi } \\
\text { ng } \\
\text { Stage }\end{array}$ & $\begin{array}{l}\text { Feature/ } \\
\text { some of in } \\
\text { Local } \\
\text { Turkish } \\
\text { Dialect }\end{array}$ & $\begin{array}{l}\text { Features in } \\
\text { Topics }\end{array}$ & $\begin{array}{l}\mathrm{T} \\
\mathrm{o} \\
\mathrm{t} \\
\mathrm{a} \\
\mathrm{l}\end{array}$ \\
\hline
\end{tabular}




\begin{tabular}{|c|c|c|c|c|c|c|c|}
\hline $\begin{array}{l}\text { Starting } \\
\text { Point } \\
\text { (First } \\
\text { Drawing) }\end{array}$ & $\begin{array}{l}\text { Arslantep } \\
\text { e Höyügü } \\
\text { (Arslante } \\
\text { pe } \\
\text { Mound) } \\
\text { Pınarbaşı }\end{array}$ & $\begin{array}{l}\text { Prehistori } \\
\text { cal } \\
\text { Archaeol } \\
\text { ogical } \\
\text { Heritage } \\
\text { Water } \\
\text { Spring }\end{array}$ & 2 & $\begin{array}{l}\text { Starting } \\
\text { Point } \\
\text { (First } \\
\text { Drawin } \\
\text { g) }\end{array}$ & $\begin{array}{l}\text { Arslantepe } \\
\text { Höyüğü } \\
\text { (Arslantepe } \\
\text { Mound) } \\
\text { Pınarbaşı }\end{array}$ & $\begin{array}{l}\text { Arslantepe } \\
\text { Höyüğü } \\
\text { (Arslantepe } \\
\text { Mound) } \\
\text { Pinarbaşı }\end{array}$ & 2 \\
\hline $\begin{array}{l}\text { Connectio } \\
\text { ns } \\
\text { (Today) }\end{array}$ & $\begin{array}{l}\text { Vaizpınar } \\
1 \\
\text { Köşebaşı } \\
\text { Elmasuyu } \\
\text { Şanlıkaya } \\
\text { Pınarbaşı } \\
\text { Çarşıbası }\end{array}$ & $\begin{array}{l}\text { District, } \\
\text { Streetna } \\
\text { me }\end{array}$ & 6 & $\begin{array}{l}\text { Connect } \\
\text { ions }\end{array}$ & $\begin{array}{l}\text { Pınarbaşı, } \\
\text { Elmasuyu } \\
\text { Köşebaşıı, } \\
\text { Çarşıbaşı } \\
\text { Kaldırım } \\
\text { Vaizpınarı }\end{array}$ & $\begin{array}{l}\text { District, } \\
\text { Streetname }\end{array}$ & 6 \\
\hline $\begin{array}{l}\text { Connectio } \\
\text { ns (Past) }\end{array}$ & $\begin{array}{l}\text { Yumru } \\
\text { Church } \\
\text { Babiki } \\
\text { Zorvari } \\
\text { Pazarbașı }\end{array}$ & $\begin{array}{l}\text { District, } \\
\text { Streetna } \\
\text { me }\end{array}$ & 4 & $\begin{array}{l}\text { Connect } \\
\text { ions } \\
\text { (Past) }\end{array}$ & $\mathrm{X}$ & $\mathbf{X}$ & 0 \\
\hline $\begin{array}{l}\text { Inter } \\
\text { connectio } \\
\text { ns } \\
\end{array}$ & $\mathbf{X}$ & $\mathbf{X}$ & 0 & $\begin{array}{l}\text { Inter } \\
\text { connect } \\
\text { ions } \\
\end{array}$ & Caget & Garden Paths & 9 \\
\hline \multirow[t]{3}{*}{$\begin{array}{l}\text { Hydrologi } \\
\text { cal } \\
\text { Features }\end{array}$} & $\begin{array}{l}\text { Margap } \\
\text { Kaldırım } \\
\text { Orduzu }\end{array}$ & $\begin{array}{l}\text { Irrigation } \\
\text { Reservoir }\end{array}$ & 3 & \multirow{3}{*}{$\begin{array}{l}\text { Hydrolo } \\
\text { gical } \\
\text { Feature } \\
\text { s }\end{array}$} & $\begin{array}{l}\text { Margap } \\
\text { Kaldırım } \\
\text { Orduzu }\end{array}$ & $\begin{array}{l}\text { Irrigation } \\
\text { Reservoir }\end{array}$ & 3 \\
\hline & $\begin{array}{l}\text { Pınar } \\
\text { Çatlak } \\
\text { Üçhavuz }\end{array}$ & $\begin{array}{l}\text { Sprinkhe } \\
\text { ad/Fount } \\
\text { ain }\end{array}$ & 3 & & $\begin{array}{l}\text { Pınar } \\
\text { Çatlak } \\
\text { Üçhavuz }\end{array}$ & $\begin{array}{l}\text { Sprinkhead/ } \\
\text { Fountain }\end{array}$ & 3 \\
\hline & $\begin{array}{l}\text { Ordu } \\
\text { Hacl }\end{array}$ & Stream & 2 & & Harık & $\begin{array}{l}\text { Water tunnel } \\
\text { (passing } \\
\text { through the } \\
\text { courtyards) }\end{array}$ & 1 \\
\hline $\begin{array}{l}\text { Agricultu } \\
\text { ral } \\
\text { Patterns } \\
\text { (Today) }\end{array}$ & $\begin{array}{l}\text { Miş miș } \\
\text { (Apricot) } \\
\text { Elma } \\
\text { (Apple) } \\
\text { Hıyar } \\
\text { (Cucumb } \\
\text { er) } \\
\text { Lahana } \\
\text { (Cabbage } \\
\text { ) } \\
\text { Tut } \\
\text { (Mulberr } \\
\text { y) } \\
\text { Ceviz } \\
\text { (Walnut) }\end{array}$ & $\begin{array}{l}\text { Agriprod } \\
\text { uct }\end{array}$ & 6 & $\begin{array}{c}\text { Agricult } \\
\text { ural } \\
\text { Pattern } \\
\text { s } \\
\text { (Today) }\end{array}$ & $\begin{array}{l}\text { Miș Miş } \\
\text { (Apricot), } \\
\text { Elma } \\
\text { (Apple), } \\
\text { Hiyar } \\
\text { (Cucumber } \\
\text { ), Lahana } \\
\text { (Cabbage), } \\
\text { Tut } \\
\text { (Mulberry), } \\
\text { Karpuz } \\
\text { (Watermel } \\
\text { on), pancar } \\
\text { (beetroot) }\end{array}$ & Agriproduct & 7 \\
\hline $\begin{array}{l}\text { Agricultu } \\
\text { ral } \\
\text { Patterns } \\
\text { (Past) }\end{array}$ & $\begin{array}{l}\text { Tütün } \\
\text { (Tobacco } \\
\text { ) (Çortik } \\
\text { Farm) } \\
\text { Gelincik } \\
\text { (Poppy) } \\
\text { Hıyar } \\
\text { (Cucumb } \\
\text { er) } \\
\text { Buğday } \\
\text { (Wheat) }\end{array}$ & $\begin{array}{l}\text { Agriprod } \\
\text { uct }\end{array}$ & 4 & $\begin{array}{l}\text { Agricult } \\
\text { ural } \\
\text { Pattern } \\
\text { s (Past) }\end{array}$ & $\begin{array}{l}\text { Tütün } \\
\text { (Tobacco) } \\
\text { Buğday } \\
\text { (Wheat) }\end{array}$ & Agriproduct & 2 \\
\hline
\end{tabular}


Exploring the Perceived Landscape with The Local People: The Experience of Community Mapping in Orduzu District (Malatya/Turkey)

\begin{tabular}{|c|c|c|c|c|c|c|c|}
\hline $\begin{array}{l}\text { Tangible } \\
\text { Cultural } \\
\text { Heritage } \\
\text { (Today) }\end{array}$ & $\begin{array}{l}\text { Kervansa } \\
\text { ray } \\
\text { Arslantep } \\
\text { e } \\
\text { Cemetery } \\
\text { Alitepe } \\
\text { Cemetery } \\
\text { Arslantep } \\
\text { e Mosque } \\
\text { Çınar, } \\
\text { Hacı'nın } \\
\text { Evi } \\
\text { (House of } \\
\text { "Hacl } \\
\text { Ali”), } \\
\text { Karamild } \\
\text { an }\end{array}$ & $\begin{array}{l}\text { Caravans } \\
\text { ary } \\
\text { Cemetery } \\
\text { mosque, } \\
\text { house, } \\
\text { monume } \\
\text { ntal tree, } \\
\text { the oldest } \\
\text { house, } \\
\text { ruins of } \\
\text { Roman } \\
\text { period }\end{array}$ & 6 & $\begin{array}{c}\text { Cultural } \\
\text { Heritag } \\
\mathrm{e} \\
\text { (Today) }\end{array}$ & $\begin{array}{l}\text { Çatlak } \\
\text { Fountain } \\
\text { Çınar }\end{array}$ & $\begin{array}{l}\text { Fountain, } \\
\text { Monumental } \\
\text { tree, }\end{array}$ & 2 \\
\hline $\begin{array}{c}\text { Tangible } \\
\text { Cultural } \\
\text { Heritage } \\
\text { (Past) }\end{array}$ & $\begin{array}{l}\text { Yumru } \\
\text { Church } \\
\text { Orduzu } \\
\text { Monastry } \\
\text { Bathouse } \\
\text { ruins } \\
\text { (Roman } \\
\text { period) } \\
\text { Military } \\
\text { tunnel } \\
\text { Mosque } \\
\text { ruins } \\
\text { Gavur } \\
\text { (unbeliev } \\
\text { er) } \\
\text { cemetery } \\
\text { Vaizpınar } \\
\text { Mound } \\
\text { Ruined } \\
\text { mill } \\
\text { Ruins in } \\
\text { Tüllük } \\
\text { Hill } \\
\text { Ruins in } \\
\text { Hill of } \\
\text { Heaven } \\
\text { Hell } \\
\text { (Gelincik } \\
\text { Hill) } \\
\text { Düzleme } \\
\text { Fountain } \\
\end{array}$ & $\begin{array}{l}\text { Church, } \\
\text { Monastry, } \\
\text { cemetery, } \\
\text { mound, } \\
\text { ruins (of } \\
\text { mosque, } \\
\text { bathhous } \\
\text { e, mill ) } \\
\text { fountain, }\end{array}$ & 11 & $\begin{array}{l}\text { Cultural } \\
\text { Heritag } \\
\text { e (Past) }\end{array}$ & $\begin{array}{l}\text { Yumru } \\
\text { Church, } \\
\text { Alitepe } \\
\text { Cemetery } \\
\text { Arslantepe } \\
\text { Cemetery, } \\
\text { Hacı'nın Evi } \\
\text { (House of } \\
\text { "Hacl Ali") } \\
\text { Esş̧ek } \\
\text { (Donkey)Sq } \\
\text { uare }\end{array}$ & $\begin{array}{l}\text { Church, } \\
\text { cemetery, } \\
\text { the oldest } \\
\text { house. } \\
\text { square }\end{array}$ & 5 \\
\hline & $\begin{array}{l}\text { Damat } \\
\text { Asma, } \\
\text { Bayram } \\
\text { sofraları } \\
\end{array}$ & $\begin{array}{l}\text { Bairam } \\
\text { rituals }\end{array}$ & 2 & & $\begin{array}{l}\text { Bayram } \\
\text { sofraları }\end{array}$ & $\begin{array}{l}\text { Bairam } \\
\text { rituals, }\end{array}$ & 1 \\
\hline $\begin{array}{l}\text { Intangibl } \\
\text { e Cultural } \\
\text { Heritage }\end{array}$ & $\begin{array}{l}\text { Gelincik } \\
\text { Hill, } \\
\text { Çatlak } \\
\text { Spring, } \\
\text { Düzleme } \\
\text { Fountain } \\
\text { Elmasuyu } \\
\text { Fountain }\end{array}$ & $\begin{array}{l}\text { Place of } \\
\text { Mysterio } \\
\text { us and } \\
\text { superstiti } \\
\text { ous } \\
\text { Beliefs }\end{array}$ & 4 & $\begin{array}{l}\text { Intangi } \\
\text { ble } \\
\text { Cultural } \\
\text { Heritag } \\
\text { e }\end{array}$ & $\begin{array}{l}\text { Arslantepe } \\
\text { Mound, } \\
\text { Arslantepe } \\
\text { Mosque, } \\
\text { Taşpınar } \\
\text { Mosque, } \\
\text { Elmasuyu } \\
\text { Cemetery, } \\
\text { Gâvur } \\
\text { cemetery, } \\
\text { Tüllük Hill, } \\
\text { Gelincik }\end{array}$ & $\begin{array}{l}\text { Place of } \\
\text { Mysterious } \\
\text { and } \\
\text { superstitious } \\
\text { Beliefs }\end{array}$ & 8 \\
\hline
\end{tabular}




\begin{tabular}{|c|c|c|c|c|c|c|c|}
\hline & & & & & $\begin{array}{l}\text { Hill, Çatlak } \\
\text { Fountain }\end{array}$ & & \\
\hline & $\begin{array}{l}\text { Terkedil } \\
\text { miş } \\
\text { konak } \\
\text { (abandon } \\
\text { ed inn) }\end{array}$ & $\begin{array}{l}\text { Terrifyin } \\
\text { g place }\end{array}$ & 1 & & $\begin{array}{l}\text { Eşşek } \\
\text { Square, } \\
\text { Elmasuyu } \\
\text { Fountain, } \\
\text { Imirgan } \\
\text { watermill, } \\
\text { Düzleme } \\
\text { Fountain }\end{array}$ & $\begin{array}{l}\text { Places used } \\
\text { in the past } \\
\text { (today not } \\
\text { excited) }\end{array}$ & 4 \\
\hline & & & & & $\begin{array}{l}\text { Telisin } \\
\text { Tutu }\end{array}$ & $\begin{array}{l}\text { Story about, } \\
\text { old garden } \\
\text { path }\end{array}$ & 1 \\
\hline & & & & & $\begin{array}{l}\text { yufka } \\
\text { ekmeği, } \\
\text { Analıkızlı, } \\
\text { Kirazyapra } \\
\text { ğl dolması, } \\
\text { lahana } \\
\text { dolması, } \\
\text { Pirpirim } \\
\text { çorbası, içli } \\
\text { köfte, pazu } \\
\text { dolması, } \\
\text { fasulye } \\
\text { yaprağı } \\
\text { dolması }\end{array}$ & $\begin{array}{l}\text { Traditional } \\
\text { Dishes }\end{array}$ & 8 \\
\hline & & & & & $\begin{array}{l}\text { Tandır } \\
\text { (house } \\
\text { oven), } \\
\text { değirmen } \\
\text { (watermill, } \\
\text { grinder, } \\
\text { water well) }\end{array}$ & $\begin{array}{l}\text { Traditional } \\
\text { garden } \\
\text { construction }\end{array}$ & 2 \\
\hline $\begin{array}{l}\text { Built } \\
\text { environm } \\
\text { ent }\end{array}$ & $\begin{array}{l}\text { Tiles } \\
\text { quarries } \\
\text { area, } \\
\text { Çarşıbaşı } \\
\text { Kıraathan } \\
\text { e, Yukarı } \\
\text { Kıraathan } \\
\text { e, Orduzu } \\
\text { primary } \\
\text { school, } \\
\text { Orduzu } \\
\text { football } \\
\text { field, } \\
\text { Cortikli } \\
\text { farm }\end{array}$ & $\begin{array}{l}\text { Educatio } \\
\text { n, } \\
\text { recreatio } \\
\text { nal } \\
\text { building, } \\
\text { coffee } \\
\text { house }\end{array}$ & 6 & $\begin{array}{l}\text { Built } \\
\text { environ } \\
\text { ment }\end{array}$ & $\begin{array}{l}\text { Own house, } \\
\text { vernacular } \\
\text { house } \\
\text { (restored), } \\
\text { some } \\
\text { residence, } \\
\text { Arslantepe } \\
\text { Mosque, } \\
\text { Orduzu } \\
\text { Elementary } \\
\text { School, } \\
\text { Football } \\
\text { field, } \\
\text { Çnarpark, } \\
\text { Barn, Zoo }\end{array}$ & $\begin{array}{l}\text { Residental, } \\
\text { regional, } \\
\text { education, } \\
\text { recreational } \\
\text { building }\end{array}$ & 9 \\
\hline
\end{tabular}


Exploring the Perceived Landscape with The Local People: The Experience of Community Mapping in Orduzu District (Malatya/Turkey)

\begin{tabular}{|c|c|c|c|c|c|c|c|}
\hline $\begin{array}{l}\text { Faunatic } \\
\text { Features }\end{array}$ & $\begin{array}{l}\text { İbibik } \\
\text { (Hoopoe), } \\
\text { Baykuş } \\
\text { (nighting } \\
\text { ale) } \\
\text { Saka } \\
\text { (goldfinc } \\
\text { h) } \\
\text { Karatavu } \\
\text { k } \\
\text { (blackbir } \\
\text { d) } \\
\text { Ağaçkaka } \\
\text { n } \\
\text { (woodpec } \\
\text { ker), } \\
\text { Arıkuşu } \\
\text { (bee- } \\
\text { eater } \\
\text { ),Gelincik } \\
\text { (weasel) } \\
\text { Sincap } \\
\text { (squirrel) } \\
\text { Kertenkel } \\
\text { e (lizard) }\end{array}$ & $\begin{array}{l}\text { Featured } \\
\text { animal } \\
\text { species } \\
\text { (bird, } \\
\text { weasel, } \\
\text { squirrel, } \\
\text { lizard) }\end{array}$ & 9 & $\begin{array}{c}\text { Faunati } \\
\text { c } \\
\text { Feature } \\
\text { s }\end{array}$ & $\mathbf{x}$ & $\mathbf{x}$ & 0 \\
\hline Flora & $\mathrm{x}$ & $\mathbf{x}$ & 0 & Flora & $\begin{array}{l}\text { Horoz } \\
\text { çiçeği } \\
\text { (eastern } \\
\text { hollyhock) } \\
\text { Isırgan } \\
\text { (stinging } \\
\text { nettle) } \\
\text { Çınar } \\
\text { (plane tree) } \\
\text { Gelincik } \\
\text { (corn } \\
\text { poppy), } \\
\text { Üzerlik otu } \\
\text { (wild rue) } \\
\text { Mış Miş } \\
\text { (Apricot), } \\
\text { Yemlik } \\
\text { (fern) }\end{array}$ & $\begin{array}{l}\text { Flowering } \\
\text { plants in the } \\
\text { home } \\
\text { gardens, and } \\
\text { fruit trees } \\
\text { (especially } \\
\text { apricot) } \\
\text { surrounding }\end{array}$ & 7 \\
\hline $\begin{array}{l}\text { Problems } \\
\text { and } \\
\text { Suggestio } \\
\text { ns }\end{array}$ & $\mathrm{x}$ & $\mathbf{x}$ & 0 & $\begin{array}{l}\text { Proble } \\
\text { ms and } \\
\text { Suggest } \\
\text { ions }\end{array}$ & $\begin{array}{l}\text { More } \\
\text { recreation } \\
\text { areas for } \\
\text { women } \\
\text { Arslantepe } \\
\text { road should } \\
\text { be a } \\
\text { pedestrian } \\
\text { way ay } \\
\text { Rehabilitati } \\
\text { on and } \\
\text { revitalisati } \\
\text { on. } \\
\text { Establishin } \\
\text { g annection } \\
\text { conn Gelincik } \\
\text { to } \\
\text { Tepe }\end{array}$ & $\begin{array}{l}\text { Problems } \\
\text { (lack of } \\
\text { playground, } \\
\text { recreation } \\
\text { areas and } \\
\text { traffic noise) } \\
\text { Suggestions } \\
\text { (on the water } \\
\text { surface and } \\
\text { new } \\
\text { connections) }\end{array}$ & 3 \\
\hline
\end{tabular}


According to the Figure 10, the most common intangible cultural heritage items are seen in the community maps drawn by both groups. Both groups provided verbal information about stories, superstitious beliefs, traditions and customs (festive rituals, etc.) under the title of intangible cultural heritage. While the male group did not express what they stated verbally in a linear fashion, they showed the locations where they told stories about the female group on their maps. Especially in the drawings about the stories, the illustrations about the religious places of the women and the illustrations about the water resources of the men come to the fore. Under this title, women drew more features than men. Both groups told and drew in detail the stories which they thought happened in the past at Gelinciktepe-Tüllüktepe, where the highest point of the neighbourhood.

Second highly drawn items are collected under the heading 'tangible cultural heritage'. Under this theme, the two groups accepted the Arslantepe Mound, the most important archaeological heritage site of the neighbourhoods, as the central point in their maps, and thus, they drew this point the first. While the male group expressed the Arslantepe Mound as an archaeological ruin, the female group used the concepts of hills and cemeteries. The male group also stated all the remains and registered structures found under the heading of tangible cultural heritage and the undetected remains and areas without any literature data on their maps. The male group correctly drew the cemetery, mosque, traditional house, monumental tree, which are registered under the title of tangible cultural heritage, and the caravanserai, which is located outside the borders of Orduzu district, according to the map location. In addition, the male group marked the archaeological remains without any information. The marked places are located around the Arslantepe Mound. (To the east of Arslantepe Mound, Tüllük remains, Cennet Cehennem Archaeological Relie, in the northeast Old mill, Roman baths ruins (drawn in 3 different regions), in the west, ruins thought to be a church or mosque, Vaizpinar Mound, in the north the military tunnel that is connected to the historical city centre of Battalgazi, which is a Seljuk period city. In the southeast, Orduzu Monastery and outside the neighborhood border Yumru Church and Gavur cemetery). Elderly members of the male group said that they had visited these areas in the past or their family elders had told the stories about these areas. The female group drew only a few items under this theme.

Third highly drawn items are collected under the theme "connections". Under this theme, it was determined that the female group drew road connections in detail (there were positioning errors). The male group drew the old town and neighbourhood boundaries and the interconnected roads in detail (the positions corresponded to the current situation. The women drew detailed garden paths as the interconnected roads, which they refer to as "cagets". 
Items found to be in the fourth density group were collected under the theme of agricultural product pattern and items. Information about the products grown in the previous years and present time is expressed both verbally and linearly.

Under the theme of built environment, the fifth densest group, the female group drew many elements, which were identified as residences, mosques, schools, recreational areas and traditional garden structures (garden ovens, etc.).

Under the theme of hydrological data, the two groups drew Pınarbaşı, the water source, together with the Arslantepe Mound. Water resources were drawn by the male group in detail.

In the mapping process, it was determined that the male group used bird species densely in Orduzu District, while the female group used plant species most. Apart from the themes created from the common elements in the mapping process, the female group expressed their problems and suggested solution about the area in which they live both verbally and linearly. The male group expressed such information verbally. Within the scope of the information obtained on the subject, it has been determined that there are significant differences in the satisfaction level of the male group and the female group concerning the area in which they live. While the female group focuses on the lack of children and sports areas in the neighbourhood, the security problem and the obsolescence of the residences, the male group states that they do not need additional children's playgrounds because the residences have a garden, and because they have strong social communication in the neighbourhood, they can immediately identify outsiders (there are coffeehouses at the node points of the district). They stated that they had no security problems for this reason. The most important problem for the male group was identified as the lack of infrastructure and unemployment. It was seen that both groups liked the area in which they live, and they do not think of living elsewhere. The main point on which the two groups related to Orduzu District agree was the Arslantepe Mound. The dominance of the male and female groups on the historical significance of the Arslantepe Mound is remarkable. They express that they owe this awareness to the excavation team. The emotional connection of the neighbourhood, which is observed to have a conservative and introverted structure in general, with the Italian excavation team is also remarkable. It has been stated that the establishment of this bond is based on years of a culture of coexistence, and at the same time, the group working in the excavation team made an economic contribution to the excavation work by choosing the residents of Orduzu District. Both groups agree that the potential of the Arslantepe Mound is not adequately described at the city and country scale and that it should be brought into tourism activities. In this sense, both groups stated that the Arslantepe Mound is the area that will provide the most economic contribution for Orduzu District and even Malatya City. 


\section{CONCLUSIONS}

This study aims to define historical landscapes through locals' perspectives and employs community mapping as a tool for defining and transferring perceived landscape elements. The study reveals that the perception of the environment varies according to gender, age, and sociocultural profile, which leads us to the conclusion that healthy and multipurpose spaces can be designed by taking these perceptional differences into account in creating spaces and maintaining spatial continuity. It is thought that the spirit of the place (genius loci) (Tuan, 1977, Norberg-Schulz, 1980,), which is absorbed by collective memory in the context of nature landscape-constructed landscape-human, holds important clues concerning how it should be transferred to constructed environments in a way that creates landscape harmony (Thayer, 1994). In this study, beyond the recognized physiographic features of the settlement, we discovered its "unseen" components due to the statements of locals and the analysis of the perceptual data they provided. Most importantly, we acquired verbal information and point data about some archaeological sites that are not mentioned in any records or literature, as they remain undiscovered. The acquired data might be a useful source for archaeological research to be conducted in the area. Moreover, the comparisons drawn by focus groups between the past and today can be counted among the data, which may also be used to spot the differences in the landscape. In addition to tangible data, memory spaces are defined according to the information acquired from the locals via an interview on intangible cultural values' interaction with space. Experience has shown the criticality of local people's participation in the experience planning processes.

There is a consensus on the view that creating plans based on traditional research methods/approaches (which fail to capture real-life dynamics and locals' expectations and problems) and hence that is out of touch with "real life" or "users" will jeopardize the continuity of the planning process (Healey, 1997, UNDP, 1998, Taylor, 1998, Ersoy, 2008, Turgut and Seçilmişler, 2017). As a result, the planning policies and decisions to be made prove to be unfeasible in the long run. Therefore, it is suggested that the use of methods such as spatial data production (on historical differences in landscape) within the mainframe of the participant planning approach and community mapping (to ensure collective wellbeing (Warren, 2013) by creating healthy, sustainable spaces) and the inclusion of these methods in spatial planning stages will prove significantly useful.

In the participatory mapping with GIS experience of Panek and Sobotova (2015), where the community mapping method was used, the authors stated that there is no clear discourse revealing the hidden potential of the study area with this method. In our study, we were able to access data not found in the literature, especially concerning archaeological remains and agricultural product patterns. Comparing the two studies, we can say that the people express their landscapes more clearly with their own 
hand drawings, without using technology; therefore, we have concluded that hidden potential can be revealed in this manner.

\section{ACKNOWLEDGEMENTS}

This paper was supported by the Scientific and Technological Research Council of Turkey (TUBITAK) under the project titled "Development of Archaeological Park Model as the Strategy for Renovating and Management of Archaeological Landscapes in Arslantepe Mound and Its Territorium" No. 2170290. Additionally, in this study carried out within the scope of this project, the research findings of the master thesis titled "The Concept of Community Mapping as a Tool for Defining Historical Landscapes: The Case Study of Orduzu (Malatya) District" were helpful. We would like to take this opportunity to thank Battalgazi Mayor, the Italian excavation team of Arslantepe Mound under the direction of Prof. Dr. Marcella Frangipane, the Mukhtar's Office of Orduzu, and the esteemed Orduzu Residents for their voluntary participation.

\section{CONFLICT OF INTEREST}

No conflict of interest was declared by the authors.

\section{FINANCIAL DISCLOSURE}

The authors declared that this study has received financial support of by the Scientific and Technological Research Council of Turkey (TUBITAK) under the project titled "Development of Archaeological Park Model as the Strategy for Renovating and Management of Archaeological Landscapes in Arslantepe Mound and Its Territorium" with project number 2170290.

\section{ETHICS COMMITTEE APPROVAL}

Ethics committee approval was not required for this article.

\section{LEGAL PUBLIC/PRIVATE PERMISSIONS}

In this research, the necessary permissions were obtained from the relevant participants during the site observations.

\section{REFERENCES}

Antrop, M. (2005). From Holistic Landscape Synthesis to Transdisciplinary Landscape Management. In: B. Tress, G. Tress, G. Fry and P. Opdam, eds. From Landscape Research to Landscape Planning: Aspects of Integration, Education and Application, Springer Press: Netherlands.

Armstrong, H. (2008). Community Mapping, In: Zoë Sofoulis, In: Armstrong, H., Bounds, M., Lopes, A. \& Andrews, T. (2008). Out \& About in Penrith: Universal Design and Cultural Context: Accessibility, Diversity and Recreational space in Penrith, unpublished report for Penrith City Council and UW 
Brown, G. (2006). Mapping Landscape Values and Development Preferences: A Method for Tourism and Residential Development Planning, International Journal of Tourism Research 8: 101-113.

Butler, A., \& Berglund, U. (2014). Landscape Character Assessment as an Approach to Understanding Public Interests within the European Landscape Convention. Landscape Research, 39 (3): 219- 236.

Cabeça, S., Gonçalves, A. R., Marques, J. F., \& Tavares, M. (2019). Mapping Intangibilities in Creative Tourism Territories Through Tangible Objects: A Methodological Approach for Developing Creative Tourism Offers. Tourism \& Management Studies, 15(SI):42-49.

Cosgrove, D., \& Daniels, S. (1988). Introduction: iconography of landscape. In: Cosgrove, D. and Daniels, S. eds. The iconography of landscape. Bath Press, Bath.

Council of Europe. (2000). Text of the European Landscape Convention. [online] [accessed 4 October 2010]. Available at: < https://www.coe.int/en/web/conventions/full-list/-

/conventions/treaty/176>.

Demir, S., \& Demirel, Ö. (2016). Korunan Havzalarda Peyzaj Değişimi ve Peyzaj Karakter Analizi ile Peyzaj Planlama Yaklaşımı: Meryemana Vadisi Örneği, Trabzon, Journal of Arts and Design, 6 (13):155-174.

Doyle, W.E. (2014). Review of Perceptions of the Prehistoric in AngloSaxon England: Religion, Ritual and Rulership in the Landscape. Papers from the Institute of Archaeology, 24(1): 1-3.

Di Nocera, G.M. (2006, April 3-8). Settlements, population and landscape on the Upper Euphrates between $V$ and II millennium BC. Results of the Archaeological Survey Project 2003-2005 in the Malatya Plain. [Paper presentation]. 5th International Congress on the Archaeology of the Ancient Near East. Universidad Autónoma de Madrid, Madrid, Spain.

Ersoy, M. (2008). Kentsel Planlama Kuramları, İmge Kitabevi, Ankara.

Fairclough, G. (2014). Landscape Character Assessment and Historical Landscape Characterisation: Conflicting, Competing, Complementary-The (Un) Necessary Evils of Disciplinary Seperation, The Future of Landscape Characterisation and The Future Character of Landscape [Seminar] Stockholm: KSLA.

Frangipane, M. (2012). The Evolution and Role of Administration in Anatolia: A Mirror of Different Degrees and Models of Centralisation. In: Balza, M.E., Giorgieri, M., \& Mora, C. eds. Archives, Depots and Storehouses in the Hittite World: New Evidence and New Research. Italian University Press, Italy.

Healey, P. (1997). Collaborative Planning: Shaping Places in Fragmented Societies, MacMillan Press, London.

Herzog, T.R., Herbert, E.J., Kaplan, R, \& Crooks, C.L. (2000). Cultural and Developmental Comparisons of Landscape Perceptions and Preferences. Environment and Behaviour, 32(3): 323-346.

Howard, P.J. (2011). An introduction to Landscape. England: Ashgate.

Human Landscape Perception. (2013). Report on understanding human landscape perception and how to integrate and implement this in current 
Exploring the Perceived Landscape with The Local People: The

Experience of Community Mapping in Orduzu District (Malatya/Turkey)

policy strategies, AONB High Weald Press, UK [online] [accessed 1404 2020]. Available at:

https://www.highweald.org/downloads/publications/uk-landscaperesearch reports/1057-human-landscape-perception-of-the-highweald/file.html>

Hunziker, M., Buchecker, M,. \& Hartig, T. (2007). Space and Place - Two Aspects of the Human-landscape Relationship. In: Kienast F., Wildi O., Ghosh S. eds. A Changing World. Landscape Series, Springer Press, Dordrecht.

Jacobs, M. (2006). The Production of Mindscapes. A Comprehensive Theory of Landscape Experience [online]. PhD thesis, University of Wageningen [accessed 10 September 2019]. Available at: < https://edepot.wur.nl/40182>.

Johnson, M. (2007). Ideas of Landscape. Blackwell: Oxford.

Johnson, L., \& Hunn, E. (2010). Landscape Ethnoecology; New York: Berghahn.

Kaplan, R., \& Herbert, E.J. (1987). Cultural and Sub-Cultural Comparisons in Preferences for Natural Settings. Landscape and Urban Planning, 14:281-293.

Kaplan, R., \& Kaplan, S. (1989). The experience of nature: A psychological perspective. Cambridge University Press: Cambridge.

Lowenthal, D. (1975). Past time present place: landscape and memory. The Geographical Review, 65 (1):1-36.

Lowenthal, D. (1985). The past is a Foreign Country. Cambridge University Press: Cambridge.

Lydon, M. F. (2002). (Re)presenting the Living Landscape: Exploring Community Mapping as a Tool for Transformative Learning and Planning. Master thesis, University of Victoria. [accessed 10 November 2019]. Available at: < https://dspace.library.uvic.ca/handle/1828/15>.

Lydon, M. (2003). Community mapping: The recovery (and discovery) of our common ground. Geomatica, 57(2): 131-143.

Lyons, E. (1983). Demographic Correlates of Landscape Preference. Environment and Behaviour, 15(4): 487-511.

Macinnes, L. (2003). Historic Landscape Characterization, In: Bishop. K and Phillips. A, eds. Countryside Planning: New Approaches to Management and Conservation, New York: Taylor \& Francis Press.

Macpherson, H. (2005). Landscape's ocular-centrism-and beyond? In: B. Tress, G. Tress, G. Fry and P. Opdam, eds. From Landscape Research to Landscape Planning. Aspects of Integration, Education and Application, Netherlands: Springer Press.

Matijosaitiene, I., Ucan, O., \& Minasyan, A. 2014. Cultural Differences in Landscape Perception, Journal of Sustainable Architecture and Civil Engineering, 3 (8): 16-25.

Norberg-Schulz, C. (1980). Genius Loci-Towards a Phenomenology of Architecture, New York: Rizzoli. 
Offen, K., \& H. (2003). Narrating Place and Identity, or Mapping Miskitu Land Claims in Northeastern Nicaragua. Human Organization, 62(4):382392.

Panek, J., \& Sobotova, L. (2015). Community Mapping in Urban Informal Settlements: Examples from Nairobi, Kenya, The Electronic Journal of Information Systems in Developing Countries (EJISDC), 68 (1): 1-13.

Parker, B. (2006). Constructing community through maps? Power and praxis in community mapping. Professional Geographer, 58(4):470-484.

Perkins, C. (2007). Community Mapping. The Cartographic Journal, 44(2):127-137.

Perera, D., \& Chandrasekara, D. P. (2017, November 10-11). Influence of Gender on Perception of Landscape: A Study of Viharamahadevi Park in Colombo. [Paper presentation]. 22 ${ }^{\text {nd }}$ International Forestry and Environment Symposium, Gangodawila, Sri Lanka

Priego, C., Breuste, J.H., \& Rojas, J. (2008). Perception References and Value of Nature in Urban Landscapes: A Comparative Analysis of Cities in Germany, Chile and Spain. Landscape Online, 7:1-22.

ScARF. (2012). Modern Panel Report. C. Dalglish and S. Tarlow (eds), People and Landscape, Perceived Landscapes: Society of Antiquaries of Scotland. [online] [accessed 14 April 2020]. Available at: <https://scarf.scot/national/scarf-modern-panel-report/8-people-andlandscape/8-3-perceived-landscapes/>.

Schenberg, T.B. (2008). Differences and Similarities in Perception of Landscape Photographs Between American-English, Spanish-Catalan and Russian Speakers. Ann Arbor: ProQuest.

Schmidt, K. (2007). Göbekli Tepe En Eski Tapınağı Yapanlar. In: Göbekli Tepe Oldest Temple Builders, trans. by R.Aslan. Istanbul: Archeology and Art Publications.

Shropshire County Council, (2007). Shropshire Landscape Assessment and Shropshire Historical Landscape Characterisation Report. [online] [accessed 10 March 2020]. Available at: <https://www.shropshire.gov.uk/environment/landscape/historiclandscape-characterisation/>.

Stular, B. (2011). Historic Landscape Characterisation, Varstvo Spomenikov (Journal for the Protection of Monuments), 46: 133-144.

Taylor, N. (1998). Urban Planning Theory Since 1945, Sage Publications, London.

Thayer, R. L. (1994). Gray World, Green Heart: Technology, Nature and the Sustainable Landscape, New York: John Wiley \& Sons.

Thomas, J. (2012). Archaeologies of place and landscape. In. I. Hodder, eds. Archaeological Theory Today, Cambridge: Polity Press.

Tuan, Yi-Fu. (2000). Space and Place the Perspective of Experience, Universite of Minnesota Press, ABD.

Turgut, S., \& Seçilmişler, T. (2017). Katılımcı Planlama Deneyimi: Mersin İl Çevre Düzeni Planı Örneği. Megaron, 12(2). 
Tudor, C. (2014). Core Document: An Approach to Landscape Character Assessment [online]. England: Natural England Press [accessed 10 April 2020]. Available at:

https://assets.publishing.service.gov.uk/government/uploads/system/ uploads/attachment_data/file/691184/landscape-characterassessment.pdf $>$.

Turner, S. (2006). Historic Landscape Characterisation: A Landscape Archaeology for Research, Management and Planning, Landscape Research, 31 (4): 385-398.

UNDP, (1998). (United Nations Development Programme), Empowering People: $A$ Guide to Participation, Available at: <http://www.undp.org/undp/csopp>.

UNECSO, (2014). Tentative List. Archaeological Site of Arslantepe, [accessed 16 May 2020]. Available at: <https://whc.unesco.org/en/tentativelists/5908/>.

UNHCR, A. (2008). A Community-Based Approach in UNHCR Operations Report. [online] [accessed 4 October 2010]. Available at:< https://www.unhcr.org/publications/legal/47ed0e212/communitybased-approach-unhcr-operations.html>.

Vale of Glamorgan Council, (2017). Community Mapping Toolkit. Booklet. [online] [accessed 8 February 2020]. Available at: < https://www.valeofglamorgan.gov.uk/Documents/Working/Regenerati on/Rural\%20Regeneration/community-mapping/community-mappingbooklet-web-english.pdf>.

Yang, B., \& Kaplan, R. (1990). The Perception of Landscape Style: A CrossCultural Comparison. Landscape and Urban Planning, 19(1990):251-262.

Yu, K. (1995). Cultural Variations in Landscape Preference: Comparisons Among Chinese Sub Groups and Western Design Experts. Landscape and Urban Planning. 32(2):107-126.

Warren, C. (2013). Community Mapping, Local Planning and Alternative Land Use Strategies in Bali, Geografisk Tidsskrift-Danish Journal of Geography, 105 (1):29-41.

Wartmann, F.M., \& Purves, S.R. (2017). What's (Not) on the Map: Landscape Features from Participatory Sketch Mapping Differ from Local Categories Used in Language, Land, 6 (79):1-16.

\section{Resume}

Bilge Hatun Ay graduated from Inonu University in Malatya with a Master's degree in landscape architecture. Her research covers several themes related cultural heritage, urban landscape, cultural and natural landscape. Regarding these topics, she took part in scientific projects.

Aysun Tuna earned her PhD from University of Ankara, Turkey. researching historical especially archaeological landscape. She previously graduated from the Universitaet für Bodenkultur (BOKU) in Vienna with a Master's degree in landscape architecture and planning. Her research covers several themes related to protection and conservation cultural heritage, integration of the cultural heritage to urban/rural landscape and the relationship between material culture- natural 
Bilge Hatun Ay \& Aysun Tuna

landscape. Regarding these topics, she is the executive of the scientific projects. She is also member of Arslantepe Mound Excavation Team since 2018. 